Optimization of Salt Marsh Management at the Edwin B. Forsythe National Wildlife Refuge, New Jersey, Through Use of Structured Decision Making

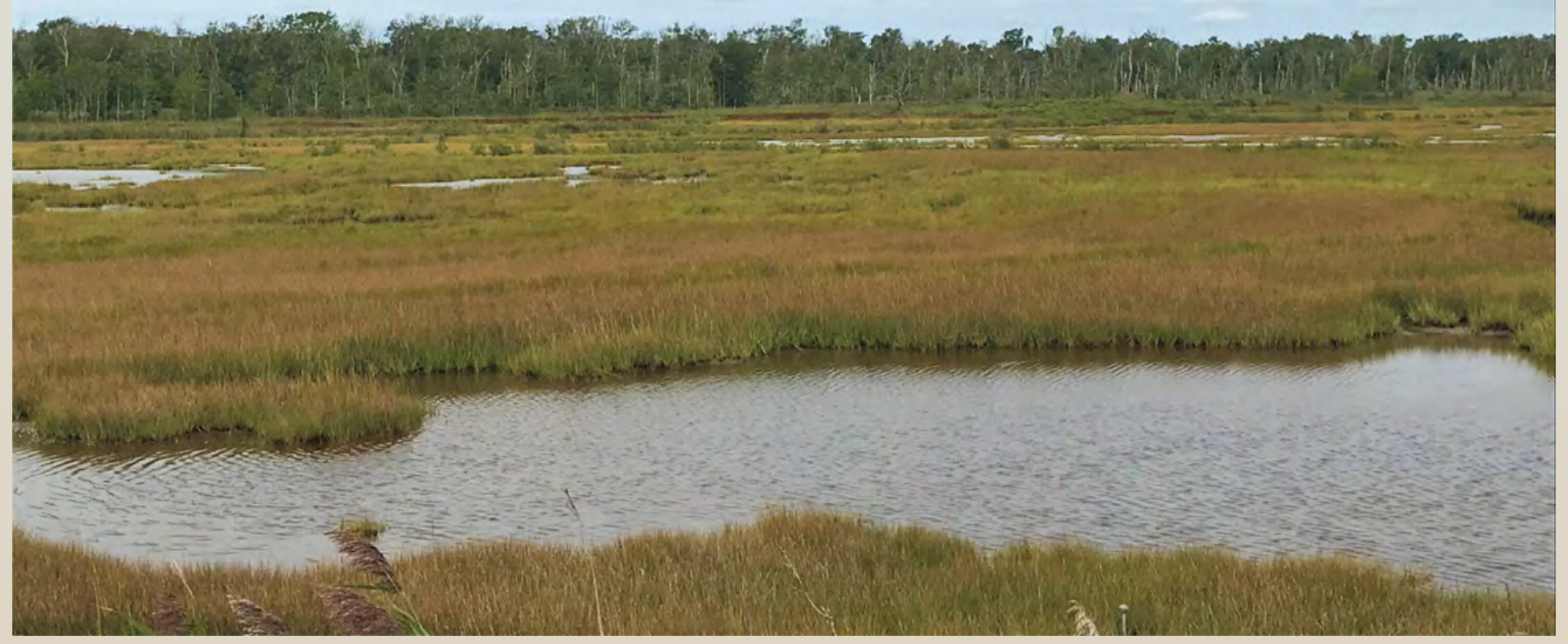

Open-File Report 2021-1037 
Cover. Photograph of AT\&T marsh at Manahawkin, New Jersey, at the Edwin B. Forsythe National Wildlife Refuge in New Jersey; photograph by the U.S. Fish and Wildlife Service. 


\section{Optimization of Salt Marsh Management at the Edwin B. Forsythe National Wildlife Refuge, New Jersey, Through Use of Structured Decision Making}

By Hilary A. Neckles, James E. Lyons, Jessica L. Nagel, Susan C. Adamowicz, Toni Mikula, Paul M. Castelli, and Virginia Rettig

Prepared in cooperation with the U.S. Fish and Wildlife Service

Open-File Report 2021-1037 


\section{U.S. Geological Survey, Reston, Virginia: 2021}

For more information on the USGS - the Federal source for science about the Earth, its natural and living resources, natural hazards, and the environment—visit https://www.usgs.gov or call 1-888-ASK-USGS.

For an overview of USGS information products, including maps, imagery, and publications, visit https://store.usgs.gov/.

Any use of trade, firm, or product names is for descriptive purposes only and does not imply endorsement by the U.S. Government.

The findings and conclusions in this report are those of the authors and do not necessarily represent the views of the U.S. Fish and Wildlife Service.

Although this information product, for the most part, is in the public domain, it also may contain copyrighted material and images protected by publicity rights. Use of photographs or images may require permission to reproduce copyrighted items or the likeness of a person. Permission must be secured from the copyright owner or person whose likeness is being used. For more information, visit https://usgs.gov/copyright.

Suggested citation:

Neckles, H.A., Lyons, J.E., Nagel, J.L., Adamowicz, S.C., Mikula, T., Castelli, P.M., and Rettig, V., 2021, Optimization of salt marsh management at the Edwin B. Forsythe National Wildlife Refuge, New Jersey, through use of structured decision making: U.S. Geological Survey Open-File Report 2021-1037, 41 p., https://doi.org/10.3133/ofr20211037.

ISSN 2331-1258 (online) 


\section{Acknowledgments}

Virginia Rettig, Rich Albers, Paul Castelli, and Shane Daley of U.S. Fish and Wildlife Service (FWS) provided exceptional hospitality for the 2016 structured decision-making workshop at the Edwin B. Forsythe National Wildlife Refuge, New Jersey. Glenn Guntenspergen, landscape ecologist with U.S. Geological Survey (USGS), and Greg Shriver, avian ecologist with University of Delaware, generously contributed their time and expertise during the workshop; their history developing metrics to assess salt marsh integrity and their knowledge of salt marsh ecosystem dynamics were extremely helpful in applying the structured decision-making framework to the Edwin B. Forsythe National Wildlife Refuge in New Jersey. Nathan Bush of the FWS generated the mapping data used in this report, and Jackie Olson of the USGS expertly prepared the maps. Technical reviews by Rachel Katz of the FWS and Bill Thompson of the National Park Service greatly improved the quality of this report. At the time of publication, data supporting this study have not been published by the U.S. Fish and Wildlife Service. 



\section{Contents}

Acknowledgments ……...................................................................................................................

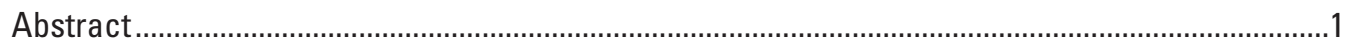

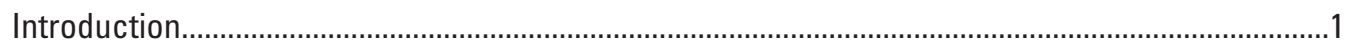

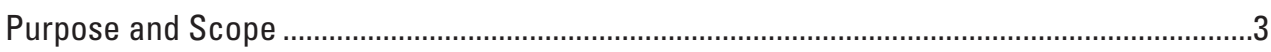

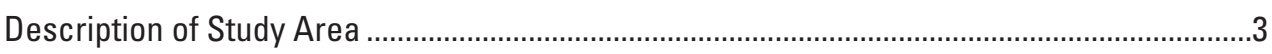

Regional Structured Decision-Making Framework ……........................................................

Application to the Edwin B. Forsythe National Wildlife Refuge ....................................................

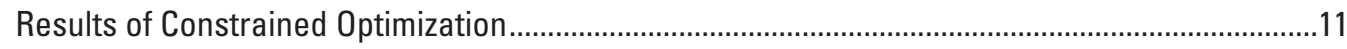

Considerations for Optimizing Salt Marsh Management..............................................................14

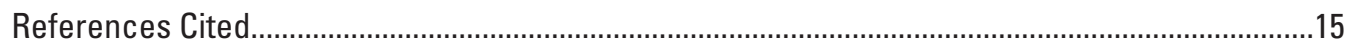

Appendix 1. Regional Influence Diagrams ............................................................................

Appendix 2. Utility Functions for the Edwin B. Forsythe National Wildlife Refuge .......................38

\section{Figures}

1. Map showing national wildlife refuges and refuge complexes of the U.S. Fish and Wildlife Service where salt marsh integrity was assessed from 2012 to 2016 ...........2

2. Map showing marsh management units of the Edwin B. Forsythe National Wildlife Refuge, New Jersey

3. Graph of predicted total management benefit of various portfolios, expressed as weighted utilities, relative to total cost at the Edwin B. Forsythe National Wildlife Refuge in New Jersey.......

4. Bar chart of predicted management benefit of portfolio 13 in comparison to the management benefit from the baseline "no-action" portfolio at the Edwin B. Forsythe National Wildlife Refuge in New Jersey.

\section{Tables}

1. Objectives hierarchy for salt marsh management decision problems.

2. Participants in the workshop convened at the Edwin B. Forsythe National Wildlife Refuge, New Jersey, to apply a regional framework for optimizing salt marsh management decisions to five national wildlife refuges in November 2016 .........10

3. Possible management actions for achieving objectives within marsh management units at the Edwin B. Forsythe National Wildlife Refuge in New Jersey, estimated costs over 5 years, and predicted outcomes expressed relative to performance metrics.

4. Normalized predicted outcomes and estimated total management benefits of possible management actions within marsh management units at the at the Edwin B. Forsythe National Wildlife Refuge in New Jersey

5. Actions included in various management portfolios to maximize the total management benefits subject to increasing cost constraints at the Edwin B. Forsythe National Wildlife Refuge in New Jersey 


\section{Conversion Factors}

International System of Units to U.S. customary units

\begin{tabular}{llll}
\hline \multicolumn{1}{c}{ Multiply } & & \multicolumn{1}{c}{ By obtain } \\
\hline meter $(\mathrm{m})$ & 3.281 & foot (ft) \\
kilometer $(\mathrm{km})$ & 0.6214 & mile (mi) \\
square meter $\left(\mathrm{m}^{2}\right)$ & 0.0002471 & acre \\
hectare (ha) & 2.471 & acre \\
\hline
\end{tabular}

\section{Datum}

Vertical coordinate information is referenced to the North American Vertical Datum of 1988 (NAVD 88).

Horizontal coordinate information is referenced to the North American Datum of 1983 (NAD 83).

Elevation, as used in this report, refers to distance above the vertical datum.

\section{Abbreviations}

FWS U.S. Fish and Wildlife Service

NWR national wildlife refuge

NWRS National Wildlife Refuge System

USGS U.S. Geological Survey 


\title{
Optimization of Salt Marsh Management at the Edwin B. Forsythe National Wildlife Refuge, New Jersey, Through Use of Structured Decision Making
}

\author{
By Hilary A. Neckles, ${ }^{1}$ James E. Lyons, ${ }^{1}$ Jessica L. Nagel, ${ }^{1}$ Susan C. Adamowicz, ${ }^{2}$ Toni Mikula, ${ }^{2}$ \\ Paul M. Castelli, ${ }^{3}$ and Virginia Rettig ${ }^{2}$
}

\section{Abstract}

Structured decision making is a systematic, transparent process for improving the quality of complex decisions by identifying measurable management objectives and feasible management actions; predicting the potential consequences of management actions relative to the stated objectives; and selecting a course of action that maximizes the total benefit achieved and balances tradeoffs among objectives. The U.S. Geological Survey, in cooperation with the U.S. Fish and Wildlife Service, applied an existing, regional framework for structured decision making to develop a prototype tool for optimizing tidal marsh management decisions at the Edwin B. Forsythe National Wildlife Refuge in New Jersey. Refuge biologists, refuge managers, and research scientists identified multiple potential management actions to improve the ecological integrity of 23 marsh management units within the refuge and estimated the outcomes of each action in terms of performance metrics associated with each management objective. Value functions previously developed at the regional level were used to transform metric scores to a common utility scale, and utilities were summed to produce a single score representing the total management benefit that could be accrued from each potential management action. Constrained optimization was used to identify the set of management actions, one per marsh management unit, that could maximize total management benefits at different cost constraints at the refuge scale. Results indicated that, for the objectives and actions considered here, total management benefits may increase consistently up to about $\$ 980,000$, but that further expenditures may yield diminishing return on investment. Potential management actions in optimal portfolios at total costs less than $\$ 980,000$ included applying sediment to the marsh surface to increase elevation in five marsh management units, digging runnels on the marsh surface to improve drainage in five marsh

\footnotetext{
${ }^{1}$ U.S. Geological Survey.

${ }^{2}$ U.S. Fish and Wildlife Service.

${ }^{3}$ U.S. Fish and Wildlife Service, retired.
}

management units, and breaching roads and berms to improve tidal flow in five marsh management units. The potential management benefits were derived from expected reduction in the duration of surface flooding, improved capacity for marsh elevation to keep pace with sea-level rise and increases in numbers of spiders (as an indicator of trophic health), tidal marsh obligate birds, and wintering American black ducks. The prototype presented here does not resolve management decisions; rather, it provides a framework for decision making at the Edwin B. Forsythe National Wildlife Refuge that can be updated as new data and information become available. Insights from this process may also be useful to inform future habitat management planning at the refuges.

\section{Introduction}

The National Wildlife Refuge System (NWRS) protects extensive salt marsh acreage in the northeastern United States. Much of this habitat has been degraded by a succession of human activities since the time of European settlement (Gedan and others, 2009), and accelerated rates of sea-level rise exacerbate these effects (Gedan and others, 2011; Kirwan and Megonigal, 2013). Therefore, strategies to restore and enhance the ecological integrity of national wildlife refuge (NWR) salt marshes are regularly considered. Management may include such activities as reestablishing natural hydrology, augmenting or excavating sediments to restore marsh elevation, controlling invasive species, planting native vegetation, minimizing shoreline erosion, and remediating contaminant problems. Uncertainty stemming from incomplete knowledge of system status and imperfect understanding of ecosystem dynamics commonly hinders management predictions and consequent selection of the most effective management options. Consequently, tools for identifying appropriate assessment variables and evaluating tradeoffs among management objectives are valuable to inform marsh management decisions.

Structured decision making is a systematic approach to improving the quality of complex decisions that integrates assessment metrics into the decision process (Gregory and 
Keeney, 2002). This approach involves identifying measurable management objectives and potential management actions, predicting management outcomes, and evaluating tradeoffs to choose a preferred alternative. From 2008 to 2012, the U.S. Geological Survey (USGS) and U.S. Fish and Wildlife Service (FWS) used structured decision making to develop a framework for optimizing management decisions for NWR salt marshes in the FWS Northeast Region (that is, salt marshes in the coastal region from Maine through Virginia). The structured decision-making steps were applied through successive "rapid prototyping" workshops, an iterative process in which relatively short periods of time are invested to continually improve the decision structure (Blomquist and others, 2010; Garrard and others, 2017). The decision framework includes regional management objectives addressing critical components of salt marsh ecosystems, and associated performance metrics for determining whether objectives are achieved (Neckles and others, 2015). The regional objectives structure served as the foundation for a consistent protocol for monitoring salt marsh integrity at these northeastern coastal refuges, in which the monitoring variables are linked explicitly to management goals (Neckles and others, 2013). From 2012 to 2016, this protocol was used to conduct a baseline assessment of salt marsh integrity at all 17 refuges or refuge complexes in the FWS Northeast Region with salt marsh habitat (fig. 1).

With about 14,000 hectares of salt marsh stretching along more than 80 kilometers of the New Jersey coast (fig. 2), the Edwin B. Forsythe National Wildlife Refuge protects one

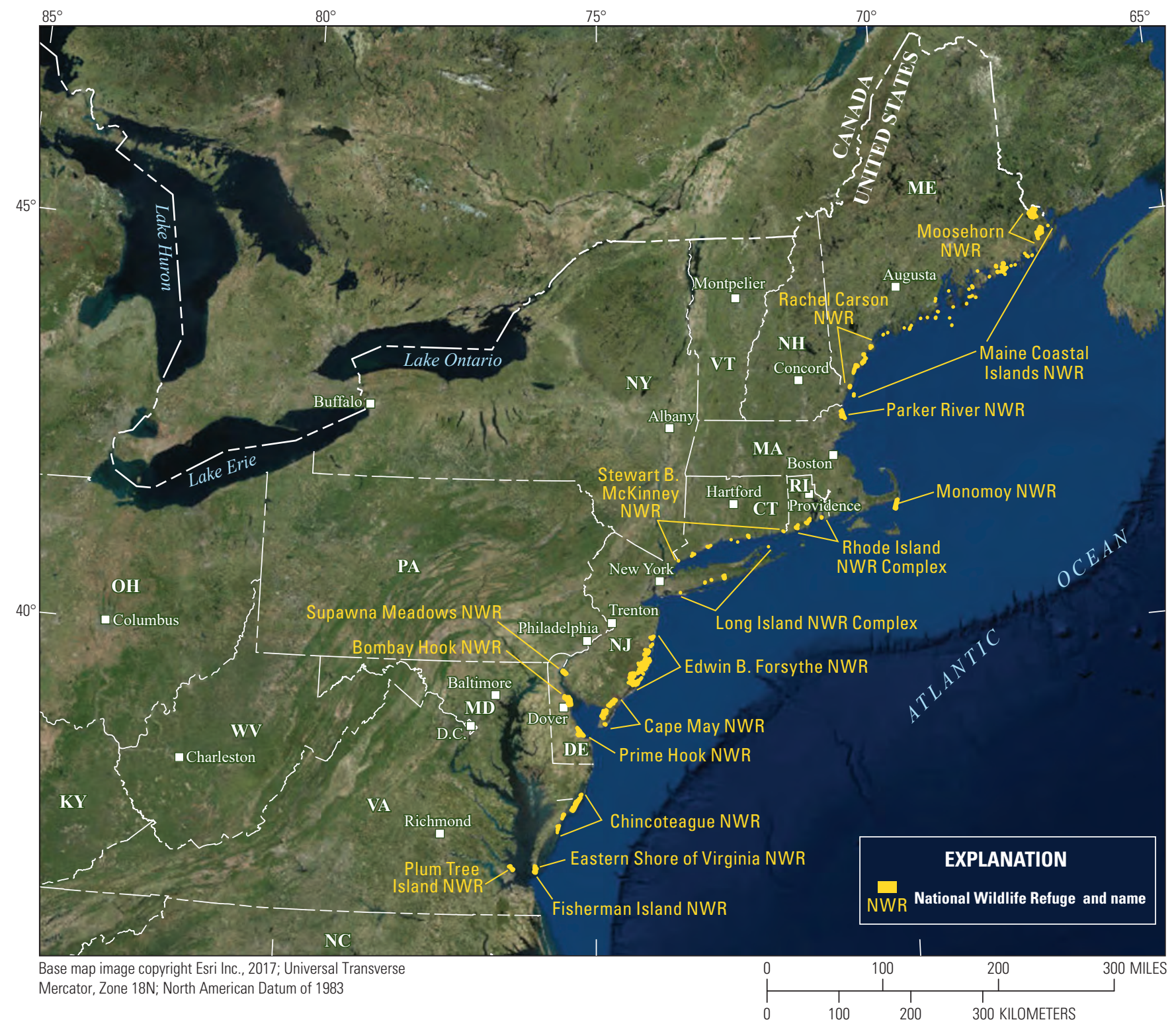

Figure 1. Map showing national wildlife refuges and national wildlife refuge complexes of the U.S. Fish and Wildlife Service where salt marsh integrity was assessed from 2012 to 2016 using the regional monitoring protocol. 
of the largest remaining expanses of salt marsh in the midAtlantic region. The refuge's salt marsh provides critical nesting, migratory, and wintering habitat for birds of highest conservation priority, including Ammodramus caudacutus (saltmarsh sparrows), Haematopus palliatus (American oystercatchers), Anas rubripes (American black ducks), and Branta bernicla (Atlantic brant) in the New England and mid-Atlantic coast U.S. North American Bird Conservation Initiative's bird conservation region (FWS, 2004; Steinkamp, 2008; U.S. North American Bird Conservation Initiative, 2020). The primary threats to this habitat are marsh submergence and habitat conversion associated with rising sea level, and, to a lesser degree, shoreline erosion and degradation associated with increasing human activity in the land surrounding the refuge (FWS, 2004, 2013). Salt-marsh management goals set by the FWS for the refuge focus on maintaining high-quality habitat for breeding, migrating, and wintering birds and restoring and enhancing habitat. In this study, the regional structured decision-making framework was used to help prioritize salt marsh management options for the refuge.

\section{Purpose and Scope}

This report describes the application of the regional structured decision-making framework (Neckles and others, 2015) to the Edwin B. Forsythe National Wildlife Refuge. The regional framework was parameterized to local conditions through rapid prototyping, producing a decision model for the refuge that can be updated as new information becomes available. Included are a suite of potential management actions to achieve objectives in 23 marsh management units at the refuge (fig. 2), approximate costs for implementing each potential action, predictions for the outcome of each management action relative to individual management objectives, and results of constrained optimization to maximize management benefits subject to cost constraints. This decision structure can be used to understand how specific actions may contribute to achieving management objectives and identify an optimum combination of actions, or "management portfolio," to maximize management benefits at the refuge scale for a range of potential budgets. The prototype presented here provides a framework for continually improving the quality of complex management decisions at the Edwin B. Forsythe National Wildlife Refuge.

\section{Description of Study Area}

The Edwin B. Forsythe National Wildlife Refuge is a salt marsh dominated system located in southern New Jersey along the Atlantic Ocean. The refuge's salt marsh spans several estuaries and is divided into 23 marsh management units. The majority of the marsh units border coastal lagoon-type estuaries (including Barnegat Bay, Little Egg Harbor, and Metedeconk River) that have small tidal ranges and limited ocean water exchange. The southernmost marsh units border a drowned river estuary system (Great Bay) with greater tidal ranges and ocean water exchange than found in the north. Most of the marsh management units have been ditched extensively for mosquito control; however, two units (Motts-Mullica Wilderness and Little Beach-Holgate; fig. 2D) lie within a federally-designated wilderness area (FWS, 2004) and protect about 2,200 hectares of unditched salt marsh. Human population growth in the region has spurred construction of housing and supporting infrastructure on property outside the refuge; much of the area between the boundaries of the marsh management units and a 1,000-meter buffer consists of developed land, as classified within the 2011 National Land Cover Database (Multi-Resolution Land Characteristics Consortium, 2020; S.C. Adamowicz and T. Mikula, FWS, unpub. data, 2017). The marsh management units are generally wellflushed with estuarine water. The invasive plant Phragmites australis (hereafter referred to as Phragmites) consistently occurs in the transition zone between upland forest and salt marsh and sporadically on high elevation sites throughout the refuge's salt marsh habitat. During 2012-14, average salt marsh surface-water salinities in the summer ranged from about 10 to about 30 parts per thousand (ppt; mesohaline to euhaline as defined by Cowardin and others, 1979) within the marsh management units (S.C. Adamowicz and T. Mikula, FWS, unpub. data, 2017). 
$\boldsymbol{A}$

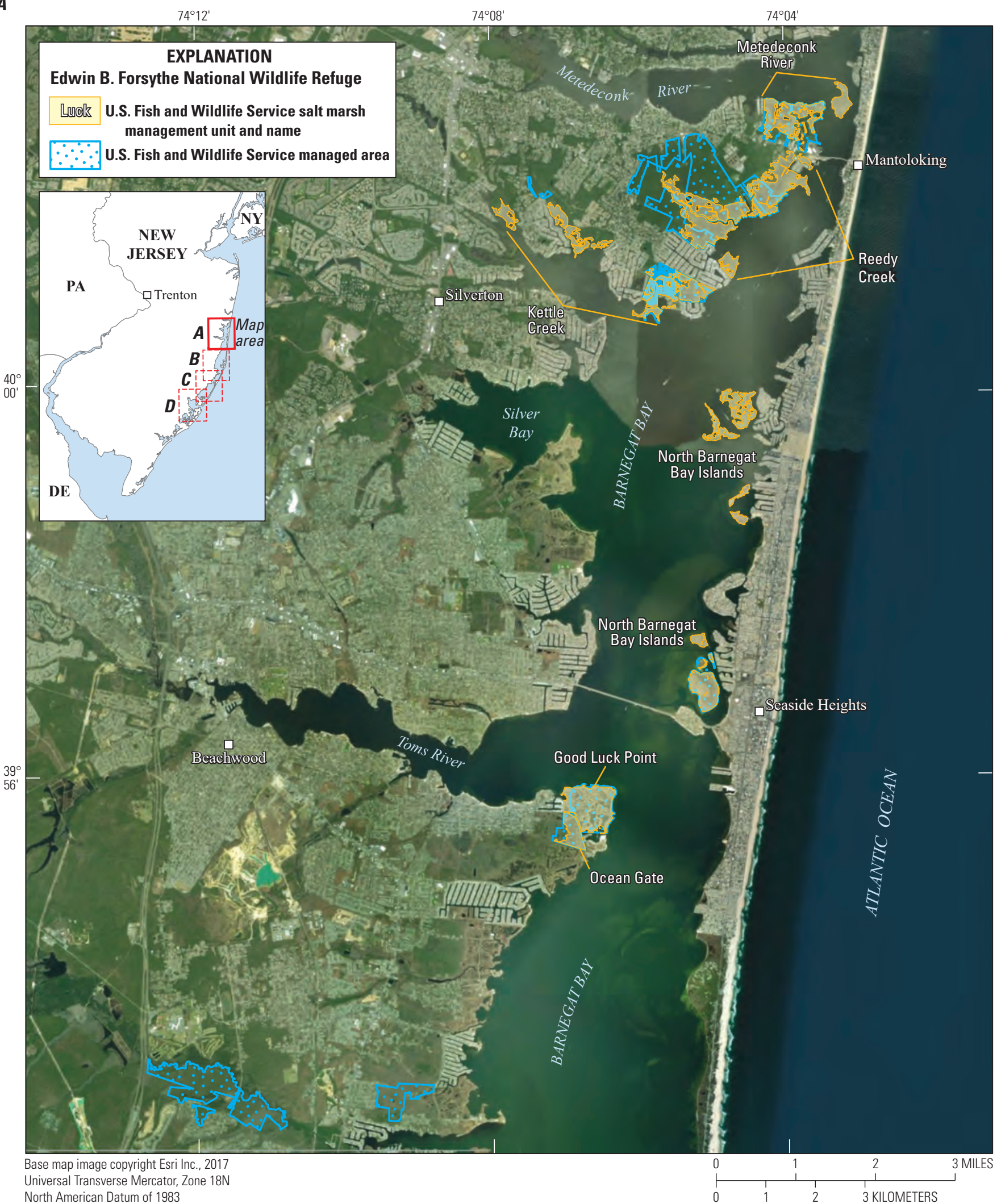

Figure 2. Map showing marsh management units at the $A$, northern, $B$, north central, $C$, south central, and $D$, southern parts of the Edwin B. Forsythe National Wildlife Refuge in New Jersey. U.S. Fish and Wildlife Service managed areas shown for reference. 
B

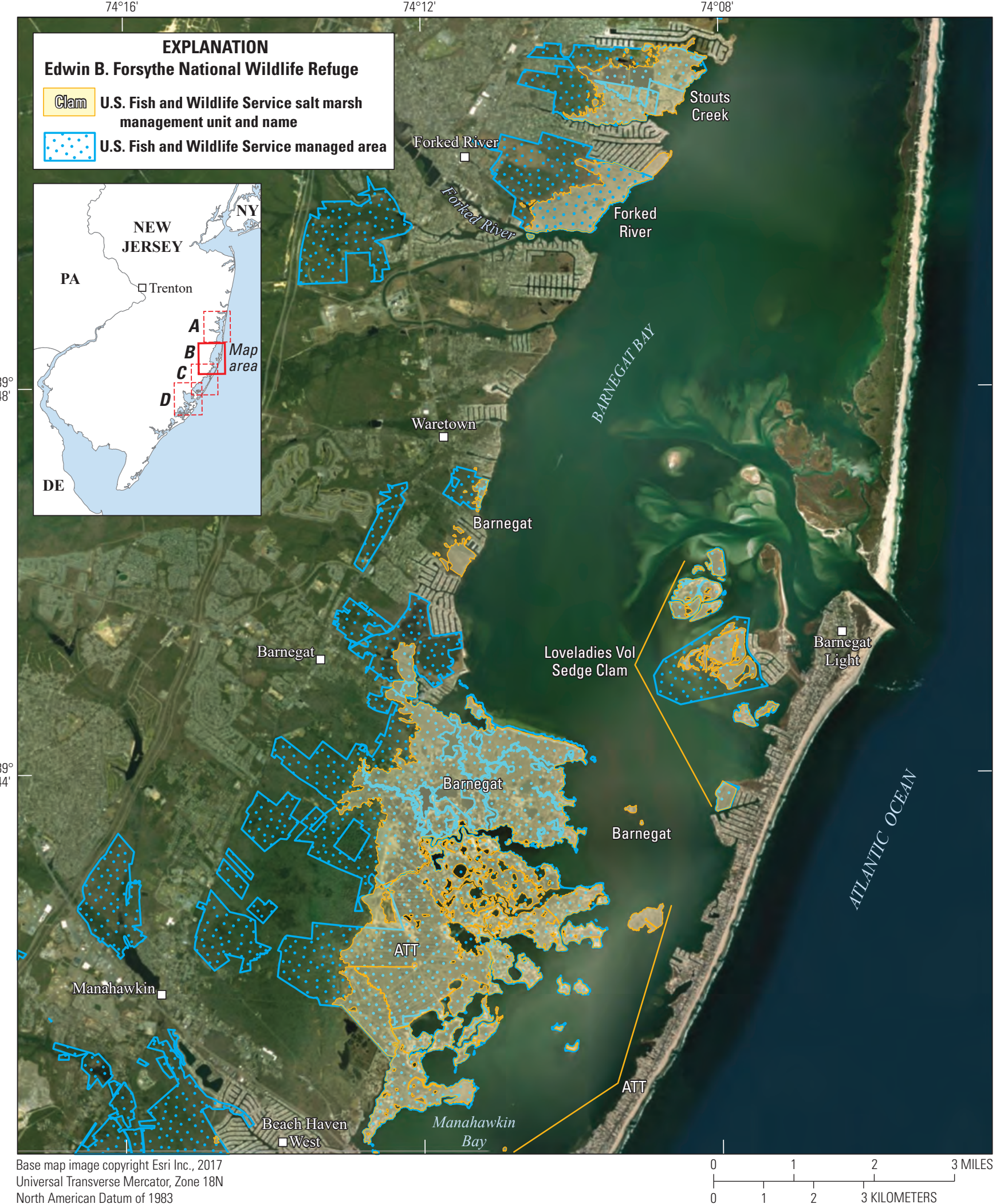

Figure 2. Map showing marsh management units at the A, northern, $B$, north central, $C$, south central, and $D$, southern parts of the Edwin B. Forsythe National Wildlife Refuge in New Jersey. U.S. Fish and Wildlife Service managed areas shown for reference.-Continued 
C

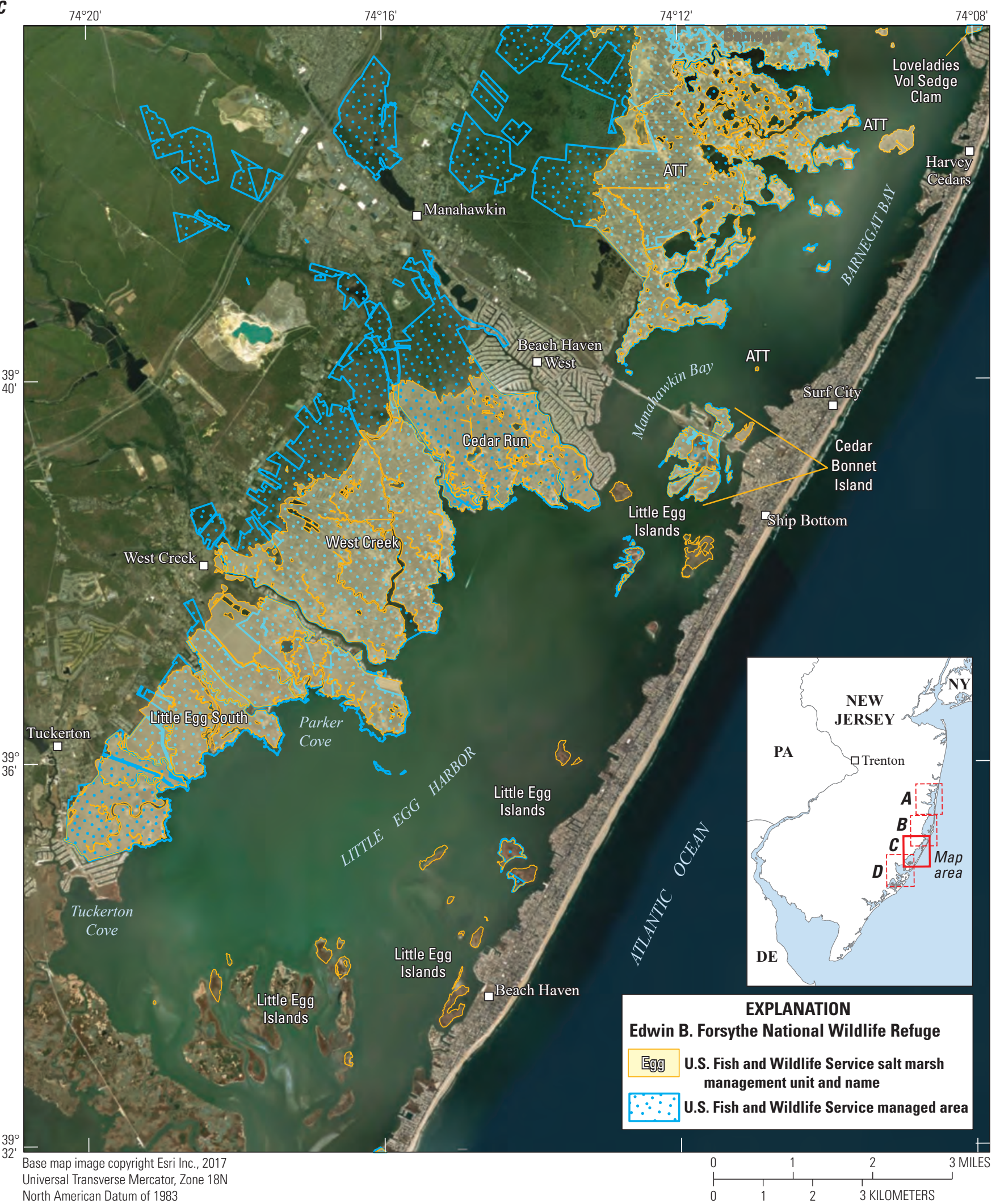

Figure 2. Map showing marsh management units at the $A$, northern, B, north central, $C$, south central, and $D$, southern parts of the Edwin B. Forsythe National Wildlife Refuge in New Jersey. U.S. Fish and Wildlife Service managed areas shown for reference.-Continued 
D

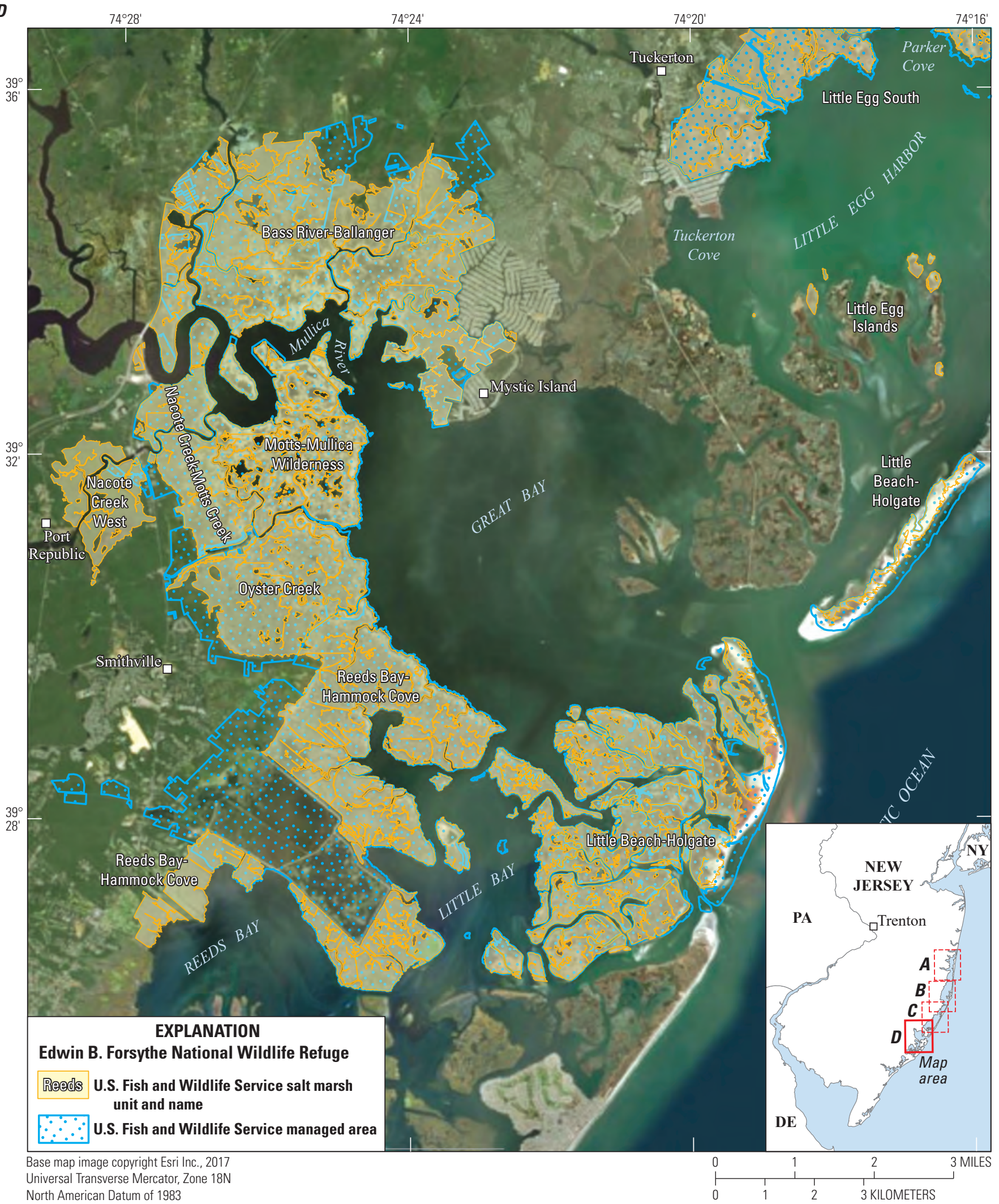

Figure 2. Map showing marsh management units at the A, northern, B, north central, $C$, south central, and D, southern parts of the Edwin B. Forsythe National Wildlife Refuge in New Jersey. U.S. Fish and Wildlife Service managed areas shown for reference.-Continued 


\section{Regional Structured Decision-Making Framework}

A regional framework for assessing and managing salt marsh integrity at northeastern NWRs was developed through collaborative efforts of FWS regional and refuge managers and biologists, salt marsh research scientists, and structured decision-making experts. This process followed the discrete steps outlined by Hammond and others (1999) and Gregory and Keeney (2002):

1. Clarify the temporal and spatial scope of the management decision.

2. Define objectives and performance measures to evaluate whether objectives are achieved.

3. Develop alternative management actions for achieving objectives.

4. Estimate the consequences or likely outcomes of management actions in terms of the performance measures.

5. Evaluate the tradeoffs inherent in potential alternatives and select the optimum alternatives to maximize management benefits.

This sequence of steps was applied through successive workshops to refine the decision structure and incorporate newly available information. Initial development of the structured decision-making framework occurred during a weeklong workshop in 2008 to define the decision problem, specify management objectives, and explore potential strategies available to restore and enhance salt marsh integrity. During 2008 and 2009, workshop results were used to guide field tests of salt marsh monitoring variables (Neckles and others, 2013). Subsequently, in 2012, data and insights gained from these field tests were used in a two-part workshop to refine management objectives and develop the means for evaluating management outcomes (Neckles and others, 2015).

From the outset, FWS goals included development of an approach for consistent assessment of salt marsh integrity across all northeastern NWRs (fig. 1). Within this regional context, staff at a given refuge must periodically determine the best approaches for managing salt marshes to maximize habitat value while considering financial and other constraints. The salt marsh decision problem was thus defined as applying to individual NWRs over a 5-year planning horizon. The objectives for complex decisions can be organized into a hierarchy to help clarify what is most important to decision makers (Gregory and others, 2012). The hierarchy of objectives for salt marsh management decisions (table 1) was based explicitly on the conservation mission of the NWRS, which is upheld through FWS management to "ensure that the biological integrity, diversity, and environmental health of the System are maintained for the benefit of present and future generations of Americans," as mandated in the National Wildlife Refuge System Improvement Act of 1997 (16 U.S.C. §668dd note). Two fundamental objectives, or the overall goals for salt marsh management decisions, were drawn from this policy to maximize (1) biological integrity and diversity, and (2) environmental health, of salt marsh ecosystems. Participants in the prototyping workshops deconstructed these overall goals further into lower level objectives relating to salt marsh structure and function and identified performance metrics to evaluate whether objectives are achieved (table 1). In addition, performance metrics were weighted to reflect the relative importance of each objective (Neckles and others, 2015).

The hierarchy of objectives for salt marsh management (table 1) provides the foundation for identifying possible management actions at individual NWRs and predicting management outcomes. Workshop participants developed preliminary influence diagrams (app. 1), or conceptual models relating management actions to responses by each performance metric (Conroy and Peterson, 2013), to guide this process. To allow metric responses to be aggregated into a single, overall performance score, participants also defined value functions relating salt marsh integrity metric scores to perceived management benefit on a common, unitless "utility" scale (Keeney and Raiffa, 1993). Stakeholder elicitation was used to determine the form of each value function relating the original metric scale to the utility scale, ranging from 0 , representing the lowest management benefit, to 1 , representing the highest benefit (app. 2). Neckles and others (2015) provided details regarding development of the structured decision-making framework and a case-study application to Prime Hook National Wildlife Refuge in Delaware. 
Table 1. Objectives hierarchy for salt marsh management decision problems.

[Two fundamental objectives (overall goals of the decision problem) draw directly from U.S. Fish and Wildlife Service (FWS) National Wildlife Refuge System policy to maintain, restore, and enhance biological integrity, diversity, and environmental health within the refuge. These are broken down into lower level objectives focused on specific aspects of marsh structure and function. Values in parentheses are weights assigned to objectives, reflecting their relative importance. Weights on any branch of the hierarchy (that is, objectives that are at the same level of the hierarchy under a fundamental objective) sum to one. The weight for each metric is the product of the weights from each level of the hierarchy leading to that metric]

\begin{tabular}{|c|c|c|}
\hline FWS objectives & Performance metrics & Unit of measurement \\
\hline \multicolumn{3}{|c|}{ Maximize biological integrity and diversity ${ }^{1}(0.5)$} \\
\hline $\begin{array}{l}\text { Maximize cover of native vegetation } \\
(0.24)\end{array}$ & Cover of native vegetation & Percent \\
\hline \multicolumn{3}{|l|}{$\begin{array}{l}\text { Maximize abundance and diversity } \\
\text { of native nekton }(0.18) \text { : }\end{array}$} \\
\hline $\begin{array}{l}\text { Maximize nekton abundance } \\
(0.50)\end{array}$ & Native nekton density & Number per square meter \\
\hline Maximize nekton diversity $(0.50)$ & Native nekton species richness & Number of native species \\
\hline $\begin{array}{l}\text { Maintain sustainable populations of } \\
\text { obligate salt marsh breeding birds } \\
(0.20)\end{array}$ & $\begin{array}{l}\text { Abundance of four species of tidal marsh ob- } \\
\text { ligate birds (clapper rail, willet, saltmarsh } \\
\text { sparrow, seaside sparrow) }\end{array}$ & $\begin{array}{l}\text { Number per marsh management unit from call- } \\
\text { broadcast surveys, summed across all sampling } \\
\text { points in unit }\end{array}$ \\
\hline $\begin{array}{l}\text { Maximize use by nonbreeding wet- } \\
\text { land birds }(0.20)\end{array}$ & $\begin{array}{l}\text { Abundance of American black duck as indica- } \\
\text { tor species }\end{array}$ & $\begin{array}{l}\text { Relative abundance for refuge during wintering } \\
\text { waterfowl season (low, medium, high) }\end{array}$ \\
\hline \multicolumn{3}{|l|}{ Maintain natural hydrology $(0.44)$ : } \\
\hline $\begin{array}{l}\text { Maintain natural flooding regime } \\
(0.50)\end{array}$ & $\begin{array}{l}\text { Percent of time marsh surface is flooded rela- } \\
\text { tive to ideal reference system }\end{array}$ & $\begin{array}{l}\text { Absolute deviation from reference in percentage } \\
\text { points }\end{array}$ \\
\hline Maintain natural salinity $(0.50)$ & $\begin{array}{l}\text { Surface-water salinity relative to ideal refer- } \\
\text { ence system }\end{array}$ & $\begin{array}{l}\text { Absolute deviation from reference in parts per } \\
\text { thousand }\end{array}$ \\
\hline $\begin{array}{l}\text { Maintain the extent of the marsh } \\
\text { platform }(0.44)\end{array}$ & $\begin{array}{l}\text { Change in marsh surface elevation relative to } \\
\text { sea-level rise }\end{array}$ & $\begin{aligned} 0= & \text { change in elevation is less than amount of sea- } \\
& \text { level rise; } 1=\text { change in elevation greater than or } \\
& \text { equal to amount of sea-level rise }\end{aligned}$ \\
\hline Minimize use of herbicides $(0.12)$ & Rate of application & $0=$ no herbicide applied; $1=$ herbicide applied \\
\hline
\end{tabular}

${ }^{1}$ Fundamental objectives of salt marsh management decisions.

${ }^{2}$ Relative abundance based on local knowledge. 


\section{Application to the Edwin B. Forsythe National Wildlife Refuge}

In November 2016, FWS regional biologists, biologists and managers from six northeastern NWR administrative units, and USGS and University of Delaware research scientists (table 2) participated in a 1.5-day rapid-prototyping workshop to apply the regional structured decision-making framework to the Chincoteague, Bombay Hook, Cape May, Supawna Meadows, and Forsythe National Wildlife Refuges and the Rhode Island National Wildlife Refuge Complex. Participants worked within refuge-specific small groups to focus on management issues at individual refuges. Plenary discussions of common patterns of salt marsh degradation, potential management strategies, and mechanisms of ecosystem response offered additional insights to enhance refugespecific discussions.

Participants identified a range of possible management actions for achieving objectives within each marsh management unit at the Edwin B. Forsythe National Wildlife Refuge and estimated the total cost of implementation over a 5-year period; the specific years of implementation were not identified in this prototype. Potential actions to enhance salt marsh integrity included restoring natural hydrology, controlling Phragmites, protecting shorelines, or altering marsh elevation or vegetation succession (table 3, in back of report). Participants predicted the outcomes of each management action 5 years after initial implementation in terms of salt marsh integrity performance metrics. For most metrics, baseline conditions within each unit measured during the 2012-16 salt marsh integrity assessment (S.C. Adamowicz and T. Mikula, FWS, unpub. data, 2017) were used to predict the outcomes of a "no-action" alternative. Baseline conditions were estimated by using expert judgement for three metrics that lacked assessment data (abundance of American black ducks, density of spiders, change in marsh surface elevation relative to sea-level rise). Regional influence diagrams relating management strategies to outcomes aided in predicting consequences of management actions (app. 1). Although the influence diagrams incorporated the potential effects of stochastic processes, including weather, sea-level rise, herbivory, contaminant inputs, and disease, on management outcomes, no attempt was made to quantify these sources of uncertainty during rapid prototyping. Management predictions also inherently included considerable uncertainty surrounding the complex interactions among controlling factors and salt marsh ecosystem components.

Following the workshop, the potential management benefit of each salt marsh integrity performance metric was calculated by converting salt marsh integrity metric scores (table 3 , workshop output) to weighted utilities (table 4 , in back of report), using regional value functions (app. 2). Weighted utilities were summed across all salt marsh integrity metrics for each action; this overall utility therefore represented the total management benefit, across all objectives, expected to accrue from a given management action (table 4). Constrained
Table 2. Participants in the workshop convened at the Edwin B. Forsythe National Wildlife Refuge, New Jersey, to apply a regional framework for optimizing salt marsh management decisions to five national wildlife refuges in November 2016.

[FWS, U.S. Fish and Wildlife Service; NWR, National Wildlife Refuge; USGS, U.S. Geological Survey]

\begin{tabular}{|c|c|}
\hline Affiliation & Participant \\
\hline \multicolumn{2}{|c|}{ FWS NWR specialists } \\
\hline Bombay Hook NWR & Susan Guiteras \\
\hline $\begin{array}{l}\text { Cape May NWR and Supawna Meadows } \\
\text { NWR }\end{array}$ & Brian Braudis \\
\hline $\begin{array}{l}\text { Cape May NWR and Supawna Meadows } \\
\text { NWR }\end{array}$ & Heidi Hanlon \\
\hline $\begin{array}{l}\text { Cape May NWR and Supawna Meadows } \\
\text { NWR }\end{array}$ & Victor Nage \\
\hline $\begin{array}{l}\text { Cape May NWR and Supawna Meadows } \\
\text { NWR }\end{array}$ & Jack Szczepanski \\
\hline Chincoteague NWR & Kevin Holcomb \\
\hline Chincoteague NWR & Jennifer Miller \\
\hline Edwin B. Forsythe NWR & Paul Castelli \\
\hline Edwin B. Forsythe NWR & Virginia Rettig \\
\hline Rhode Island NWR Complex & Nick Ernst \\
\hline Rhode Island NWR Complex & Charlie Vandemoer \\
\hline \multicolumn{2}{|c|}{ FWS regional experts } \\
\hline Northeast Regional Office & Laura Mitchell \\
\hline Rachel Carson NWR & Susan Adamowicz \\
\hline Rachel Carson NWR & Toni Mikula \\
\hline \multicolumn{2}{|l|}{ Research scientists } \\
\hline University of Delaware & W. Gregory Shriver \\
\hline USGS Eastern Ecological Science Center & Glenn Guntenspergen \\
\hline USGS Eastern Ecological Science Center & James Lyons \\
\hline USGS Eastern Ecological Science Center & Hilary Neckles \\
\hline
\end{tabular}

optimization (Conroy and Peterson, 2013) was used to find the management portfolio (the combination of actions, one action per marsh management unit) that maximizes the total management benefit across all units under varying cost scenarios for the entire the refuge. Constrained optimization using integer linear programming was implemented in the Solver tool in Microsoft Excel (Kirkwood, 1997). Budget constraints were increased in $\$ 5,000$ increments up to $\$ 50,000$; in $\$ 50,000$ increments up to $\$ 200,000$; in $\$ 100,000$ increments up to $\$ 1$ million; in $\$ 500,000$ increments up to $\$ 2.5$ million; and in $\$ 5$ million increments thereafter. The upper limit to potential costs was not determined in advance; rather, it reflected the total estimated costs of the proposed management actions. A cost-benefit plot of the portfolios identified through the optimization analysis was used to identify the efficient frontier for resource allocation (Keeney and Raiffa, 1993), which is the set of portfolios that are not dominated by other portfolios at similar costs (or the set of portfolios with maximum total benefit for a similar cost). The cost-benefit plot also revealed the 
cost above which further expenditures would yield diminishing returns on investment. To exemplify use of the decisionmaking framework to understand how a given portfolio could affect specific management objectives, the refuge-scale management benefits for individual performance metrics were compared between one optimal portfolio and those predicted with no management action taken.

\section{Results of Constrained Optimization}

Potential management actions identified to improve marsh integrity at the Edwin B. Forsythe National Wildlife Refuge included adding sediment to the marsh surface to increase elevation; establishing living shorelines (plants or other natural elements for shoreline stabilization) to help protect the salt marsh edge from erosion; restoring natural hydrology through breaching berms and digging shallow runnels on the marsh surface; and spraying herbicide to control Phragmites (table 3). For costs ranging from $\$ 0$ to $\$ 16.5$ million, the estimated management benefits for individual actions across all metrics, measured as weighted utilities, ranged from 0.399 (for implementing no action in the Kettle Creek marsh management unit) to 0.976 (for restoring openwater salt hay farms to marsh in the Cedar Run marsh management unit), out of a maximum possible total management benefit of 1.0 (tables 3 and 4). In each marsh management unit, the alternative with both the lowest management benefit and lowest cost was generally the "no action" alternative (action A); however, for Stouts Creek, Barnegat, and Forked River marsh management units, actions to breach berms for improving tidal flow would be accomplished through a partner contribution, and thus also had no associated cost. In addition, in many marsh management units, controlling Phragmites through herbicide use yielded a lower total management benefit than implementing no management actions.

Constrained optimization was applied to identify the optimal management portfolios over 5 years for a range of total costs to the refuge. As total cost increased from $\$ 0$ (no action in most units) to about $\$ 9.65$ million, the total management benefit at the refuge scale increased from 15.483 to 19.345 (a 25-percent increase; table 5), out of a possible maximum of 23.0 (the maximum possible total management benefit of 1.0 for any management action, summed across 23 marsh management units). Graphical analysis showed a fairly consistent increase in management benefit as costs increased to about $\$ 982,000$ (fig. 3, portfolio 13). Portfolio 13 represented a turning point in the cost-benefit plot. As expenditures increased beyond the cost of portfolio 13, total management benefit continued to increase but at a lower rate, yielding diminishing returns on investment; there was very little gain in management benefit for expenditures greater than about $\$ 2$ million (fig. 3, portfolio 15).

Several patterns emerged relative to the potential management actions selected by constrained optimization within the set of portfolios that yielded the greatest total management benefit per unit cost (table 5, portfolios 2 through 13). Actions that could enhance or restore marsh hydrology, including digging runnels or breaching berms to improve tidal flow, were always included in the optimal portfolios (involving ATT, West Creek, Oceangate, North Barnegat Bay Islands, Good Luck Point, Stouts Creek, Barnegat, Cedar Bonnet Island, Little Egg South, Forked River, and Cedar Run marsh management units). At five marsh management units (Loveladies Vol Sedge Clam, Metedeconk River, Reedy Creek, Kettle Creek, and Little Egg Islands), sediment enrichment was the primary management action included in portfolios 2 through 13, whereas at six units (Oyster Creek, MottsMullica Wilderness, Bass River-Ballanger, Nacote CreekMotts Creek, Nacote Creek West, and Reeds Bay-Hammock Cove), the no-action alternative was selected consistently. In contrast, other management actions were never or rarely included in an optimal portfolio at a cost of less than \$1 million. Although installation of living shorelines was identified to reduce marsh-edge erosion for most marsh management units, this action was rarely selected; living shorelines were never included in optimal portfolios costing less than \$1 million, and were included in more costly portfolios for four units only (Bass River-Ballinger, Nacote Creek-Motts Creek, Nacote Creek West, and Reeds Bay-Hammock Cove marsh management units). Similarly, spraying herbicide to control Phragmites was identified to improve integrity of many marsh management units, but this action was never selected during constrained optimization.

Examination of the refuge-scale metric responses to actions included in portfolio 13, which is the turning point in the cost-benefit plot (fig. 3), revealed how implementation could affect specific management objectives. The actions included in portfolio 13 were predicted to achieve large gains in the overall management benefits derived from increased density of spiders (as an indicator of trophic health), reduced duration of flooding, and the capacity of marsh elevation to keep pace with sea-level rise, and modest gains in the benefits derived from changes to the nekton density, numbers of tidal marsh obligate birds, and American black ducks in winter (fig. 4). Ecologically, the combination of actions in this portfolio predicted an average 213-percent increase in tidal marsh obligate bird counts (averaged across all marsh management units), 465-percent increase in spider density, 52-percent increase in nekton density, and 35-percent decrease in the deviation of surface flooding from the ideal reference condition (derived as the average difference between the predicted metric scores for the actions implemented in portfolio 13 and the "no-action" alternative; table 3). Implementation of actions in this portfolio was predicted also to improve the capacity for marsh elevation to keep pace with sea-level rise in 5 of the 23 marsh management units. The management benefits predicted for portfolios 1 through 12, at total costs up to about $\$ 886,000$, were derived primarily from expected improvements in surface-water drainage and consequent flooding duration, and presumed increases in densities of spiders, numbers of tidal marsh obligate birds, and capacity for marsh elevation to keep pace with sea-level rise (tables 3 and 4). 


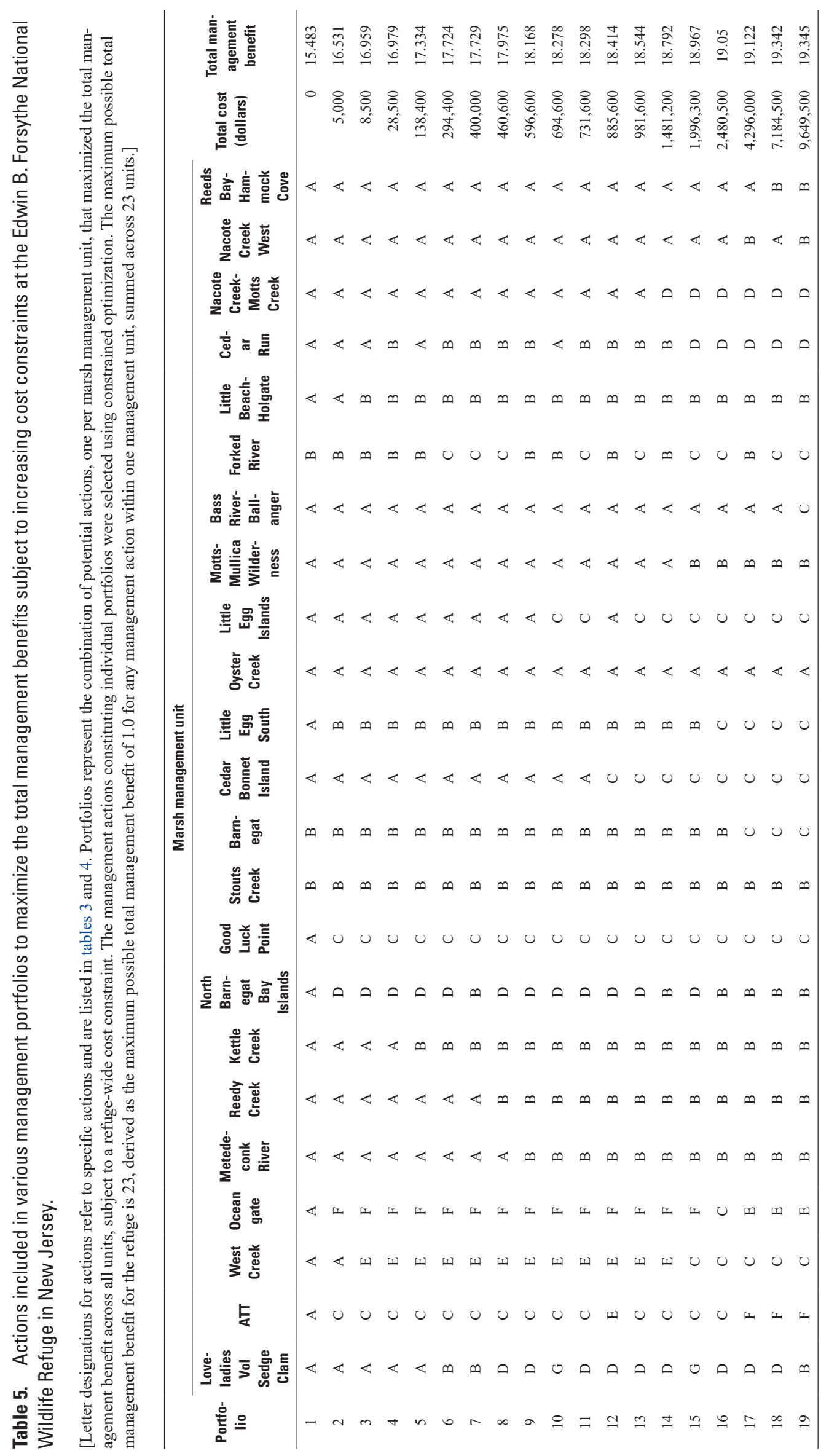




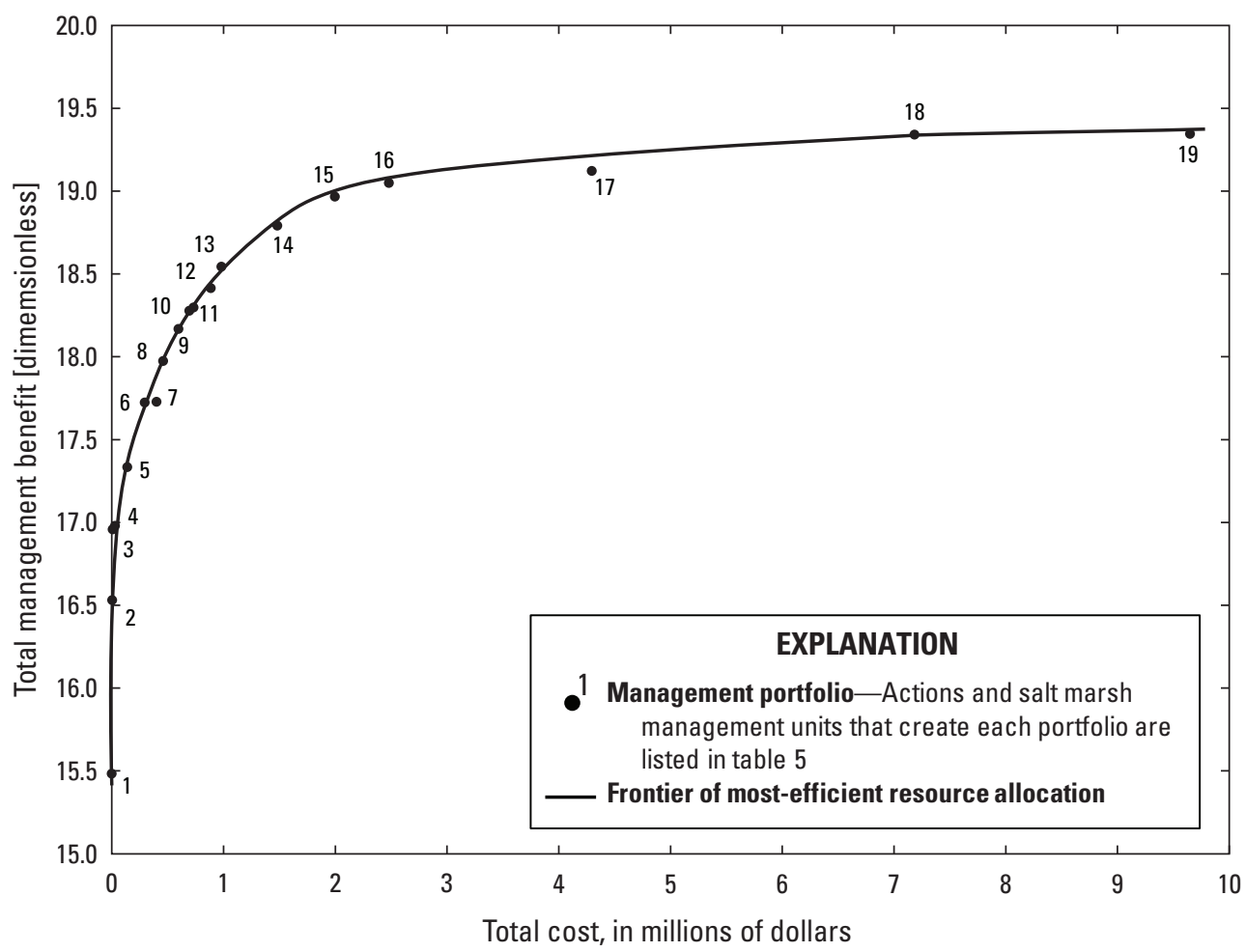

Figure 3. Graph showing predicted total management benefit of various portfolios, expressed as weighted utilities, relative to total cost at the Edwin B. Forsythe National Wildlife Refuge in New Jersey. Each portfolio (dot with number) represents a combination of 23 management actions, one per marsh management unit, as identified in table 5 . The line represents the efficient frontier for resource allocation.

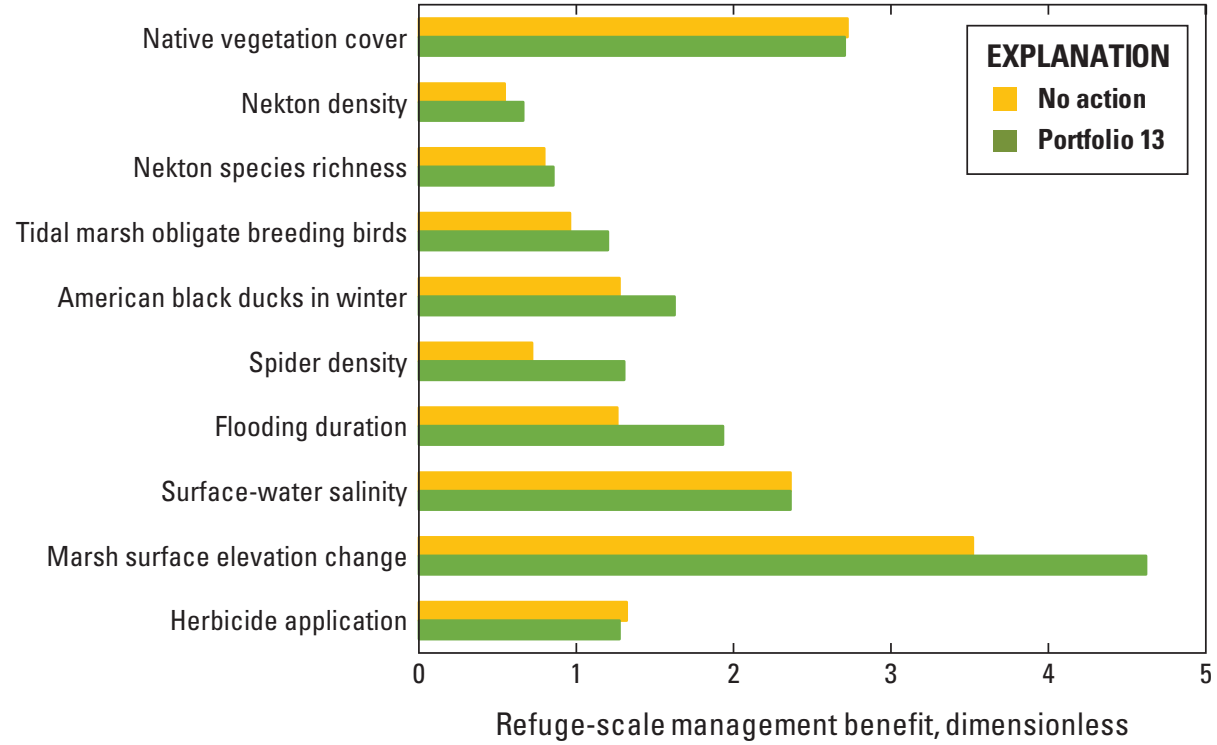

Figure 4. Predicted management benefit at the refuge scale for individual performance metrics, expressed as weighted utilities, resulting from implementation of the management actions included in portfolio 13, in comparison to the management benefit from the baseline "no-action" portfolio, at the Edwin B. Forsythe National Wildlife Refuge in New Jersey. The actions included in each portfolio are listed in table 5 . 


\section{Considerations for Optimizing Salt Marsh Management}

A regional structured decision-making framework for salt marshes on NWRs in the northeastern United States was applied by the USGS, in cooperation with the FWS, to develop a tool for optimizing management decisions at the Edwin B. Forsythe National Wildlife Refuge. Use of the existing regional framework and a rapid-prototyping approach permitted NWR biologists and managers, FWS regional authorities, and research scientists to construct a decision model for the refuge within the confines of a 1.5-day workshop. This preliminary prototype provides a local framework for decision making while revealing information needs for future iterations. Insights from this process may also be useful to inform future habitat management planning at the refuge.

The suite of potential management actions and predicted outcomes included in this prototype (table 3 ) were based on current understanding of the Edwin B. Forsythe National Wildlife Refuge salt marshes and hypothesized process-response pathways (app. 1). Multiple, interacting factors influence the long-term success of restoration actions in prolonging marsh integrity and improving marsh resilience (Roman, 2017). Tidal flooding is the predominant physical control on the structure and function of salt marsh ecosystems (Pennings and Bertness, 2001), and there is widespread scientific effort to elucidate how salt marshes may respond to accelerating rates of sea-level rise and management strategies to enhance their sustainability (Kirwan and Megonigal, 2013; Roman, 2017). Thin-layer deposition of sediments to raise marsh elevation and excavation of runnels, or shallow creeks, to improve surface drainage are increasingly proposed to enhance sustainability of northeastern salt marshes threatened with submergence, although responses to these management actions may depend on many site-specific factors (Wigand and others, 2017). In this prototype, the high management benefit predicted to accrue from sediment enhancement and runnel creation led to the frequent selection of these actions within optimal portfolios. However, in a Rhode Island study, excavation of runnels to partially drain ponded water from salt marsh surfaces assisted in maintaining cover by high-marsh vegetation (Spartina patens), whereas sediment enhancement did not (Perry, 2020). Ultimately, the conversion of uplands to wetlands driven by sea-level rise may be the most important determinant of future marsh area. In the absence of anthropogenic barriers to marsh migration, land conversion is controlled by the slope and cover of coastal uplands; the stresses to upland vegetation caused by salinity and inundation; and synergistic disturbance events such as storms and insect outbreaks (Kirwan and Gedan, 2019). In Delaware Bay, Phragmites frequently invades the zone of retreating forest, forming a fringing band at the salt marsh-forest ecotone that can impede inland salt marsh migration (Smith 2013). In this prototype, removing dead trees and killing Phragmites was hypothesized as a possible management action to facilitate marsh migration in eight marsh management units (table 3), but there was little information available to inform the predicted consequences. Future iterations of this decision model can incorporate improved understanding of the potential for marsh migration and processes controlling marsh responses to management actions. In addition, during construction of the regional decision model, a lack of widely available data on rates of vertical marsh growth led to the adoption of a very coarse scale of measurement for change in marsh surface elevation relative to sea-level rise (table 1). In 2014, surface elevation tables (Lynch and others, 2015) were installed in 14 marsh management units to obtain high-resolution measurements of change in marsh surface elevation (S.C. Adamowicz and T. Mikula, FWS, unpub. data, 2017). Incorporating this information into subsequent iterations of this structured decision-making framework would likely improve predictions related to the potential for marsh surface elevation to keep pace with sealevel rise.

Results of constrained optimizations (table 5) based on the objectives, management actions, and predicted outcomes included in this prototype identified four major areas in which to improve the utility of the prototype for decision making at the Edwin B. Forsythe National Wildlife Refuge. First, although loss of marsh area through shoreline erosion is a concern in some areas within the marsh complex, reducing wave action through the construction of living shorelines was generally excluded from optimal portfolios. Living shorelines may not be a practical management option at this refuge. Additionally, deconstructing the objective of maintaining the extent of the marsh platform into subordinate objectives and performance metrics related to both horizontal and vertical gains and losses may help focus decision making on the various drivers of marsh area. Second, the transparency of the structured decision-making framework reveals the tradeoffs associated with using herbicide to control Phragmites; the predicted increases in management benefit associated with various aspects of marsh structure and function did not outweigh the predicted decrease in management benefit associated with chemical application (table 4). Where spread of Phragmites is a management concern at the Edwin B. Forsythe National Wildlife Refuge, this prototype could be adapted to allow managers to evaluate the relative expected benefits and detriments of chemical and other control methods. These results emphasize the importance that refuge managers have already placed on considering methods in addition to herbicides, including prescribed burning, biological control, and hydrologic restoration, to control Phragmites through an integrated approach (FWS, 2013). Third, there were multiple marsh management units for which the no-action alternative was selected for the optimal portfolios at either all or nearly all of the total cost constraints (table 5). Rapid prototyping did not allow indepth analysis of the causes of marsh degradation and potential management actions in all 23 marsh management units, and managers may want to explore additional methods for improving marsh integrity in some units. Recent research has synthesized multiple spatial datasets from Edwin B. Forsythe 
National Wildlife Refuge to locate the marsh areas that are most vulnerable to degradation (Defne and others, 2020), and Neeson and others (2016) showed that the cost of restoration in general may be lower at sites with a small number of severe problems than at sites with more numerous but less severe problems. This type of information could be used to prioritize investments among the marsh management units in planning, applications of the decision model, and assessments. Finally, the constrained optimizations analyzed in this report were based on approximations of management costs. As salt marsh management is undertaken around the region, a detailed list of actual expenses can be compiled, including staff time for project planning as well as materials, equipment, contracts, and staff time for implementation. This will allow future iterations of the decision model to include more accurate cost estimates.

The prototype model for the Edwin B. Forsythe National Wildlife Refuge provides a useful tool for decision making that can be updated in the future with new data and information. The spatial and temporal variability inherent in parameter estimates were not quantified during rapid prototyping. Previously, preliminary sensitivity analysis revealed little effect of incorporating ecological variation in abundance of marsh-obligate breeding birds on the optimal solutions for Prime Hook National Wildlife Refuge (Neckles and others, 2015). This lends confidence to use of this framework for decision making; however, including probability distributions for each performance metric in the decision model could be a high priority for future prototypes. Future monitoring of salt marsh integrity performance metrics will be useful to refine baseline parameter estimates and to determine the background rate of change in the absence of management actions, and feedback from measured responses to management actions around the region will help reduce uncertainties surrounding management predictions. The structured decision-making framework applied here to the Edwin B. Forsythe National Wildlife Refuge is based on a hierarchy of regional objectives and regional value functions relating performance metrics to perceived management benefits. It will be important to ensure that subsequent iterations reflect evolving management objectives and desired outcomes. Elements of the decision model could be further adapted, for example through differential weighting of objectives or altered value functions, to reflect specific, local management goals and mandates. Future optimization analyses that use this framework could also incorporate additional constraints on action selection, such as ensuring that particular actions within individual marsh management units are included in optimal management portfolios, to further tailor the model to refuge-specific needs.

\section{References Cited}

Blomquist, S.M., Johnson, T.D., Smith, D.R., Call, G.P., Miller, B.N., Thurman, W.M., McFadden, J.E., Parkin, M.J., and Boomer, G.S., 2010, Structured decision-making and rapid prototyping to plan a management response to an invasive species: Journal of Fish and Wildlife Management, v. 1, no. 1, p. 19-32. [Also available at https://doi.org/ 10.3996/JFWM-025.]

Conroy, M.J., and Peterson, J.T., 2013, Decision making in natural resource management-A structured, adaptive approach: Chichester, United Kingdom, John Wiley and Sons, Ltd., 456 p. [Also available at https://doi.org/10.1002/ 9781118506196.]

Cowardin, L.M., Carter, V., Golet, F.C., and LaRoe, E.T., 1979, Classification of wetlands and deepwater habits of the United States: U.S. Fish and Wildlife Service report FWS/OBS-79/31, 131 p., accessed November 12, 2018, at https://www.fws.gov/wetlands/Documents/Classification-ofWetlands-and-Deepwater-Habitats-of-the-United-States.pdf.

Defne, Z., Aretxabaleta, A.L., Ganju, N.K., Kalra, T.S., Jones, D., and Smith, K.E.L., 2020, A geospatially resolved wetland vulnerability index-Synthesis of physical drivers: PLoS One, v. 15, no. 1, e0228504. [Also available at https://doi.org/10.1371/journal.pone.0228504.]

Garrard, G.E., Rumpff, L., Runge, M.C., and Converse, S.J., 2017, Rapid prototyping for decision structuringAn efficient approach to conservation decision analysis, in Bunnefeld, N., Nicholson, E., and Milner-Gulland, E.J., eds., Decision-making in conservation and natural resource management: Cambridge, United Kingdom, Cambridge University Press, p. 46-64. [Also available at https://doi.org/10.1017/9781316135938.003.]

Gedan, K.B., Altieri, A.H., and Bertness, M.D., 2011, Uncertain future of New England salt marshes: Marine Ecology Progress Series, v. 434, p. 229-237. [Also available at https://doi.org/10.3354/meps09084.]

Gedan, K.B., Silliman, B.R., and Bertness, M.D., 2009, Centuries of human-driven change in salt marsh ecosystems: Annual Review of Marine Science, v. 1, no. 1, p. 117-141. [Also available at https://doi.org/10.1146/ annurev.marine.010908.163930.]

Gregory, R., Failing, L., Harstone, M., Long, G., McDaniels, T., and Ohlson, D., 2012, Structured decision making-A practical guide to environmental management choices: Chichester, United Kingdom, John Wiley and Sons, Ltd., 299 p. [Also available at https://doi.org/10.1002/ 9781444398557.] 
Gregory, R.S., and Keeney, R.L., 2002, Making smarter environmental management decisions: Journal of the American Water Resources Association, v. 38, no. 6, p. 1601-1612. [Also available at https://doi.org/10.1111/ j.1752-1688.2002.tb04367.x.]

Hammond, J.S., Keeney, R.L., and Raiffa, H., 1999, Smart choices-A practical guide to making better life decisions: Boston, Harvard Business School Press, 242 p.

Keeney, R.L., and Raiffa, H., 1993, Decisions with multiple objectives - Preferences and value tradeoffs: Cambridge, United Kingdom, Cambridge University Press, 569 p. [Also available at https://doi.org/10.1017/CBO9781139174084.]

Kirkwood, C.W., 1997, Strategic decision makingMultiobjective decision analysis with spreadsheets: Belmont, Calif., Duxbury Press, 345 p.

Kirwan, M.L., and Gedan, K.B., 2019, Sea-level driven land conversion and the formation of ghost forests: Nature Climate Change, v. 9, p. 450-457. [Also available at https://doi.org/10.1038/s41558-019-0488-7.]

Kirwan, M.L., and Megonigal, J.P., 2013, Tidal wetland stability in the face of human impacts and sea-level rise: Nature, v. 504, no. 7478, p. 53-60. [Also available at https://doi.org/ 10.1038 /nature 12856.$]$

Lynch, J.C., Hensel, P., and Cahoon, D.R., 2015, The surface elevation table and marker horizon technique-A protocol for monitoring wetland elevation dynamics: National Park Service Natural Resource Report NPS/NCBN/NRR 2015/1078, [variously paged], accessed August 24, 2018, at https://irma.nps.gov/DataStore/DownloadFile/531681.

Multi-Resolution Land Characteristics Consortium, 2020, NLCD 2011 land cover (CONUS): Multi-Resolution Land Characteristics Consortium database, accessed March 1, 2021, at https://www.mrlc.gov/data.

Neckles, H.A., Guntenspergen, G.R., Shriver, W.G., Danz, N.P., Wiest, W.A., Nagel, J.L., and Olker, J.H., 2013, Identification of metrics to monitor salt marsh integrity on national wildlife refuges in relation to conservation and management objectives-Final report-January 2013: U.S. Fish and Wildlife Service, prepared by U.S. Geological Survey, 226 p., accessed May 1, 2018, at https://eco s.fws.gov/ServCat/Reference/Profile/37795.

Neckles, H.A., Lyons, J.E., Guntenspergen, G.R., Shriver, W.G., and Adamowicz, S.C., 2015, Use of structured decision making to identify monitoring variables and management priorities for salt marsh ecosystems: Estuaries and Coasts, v. 38, no. 4, p. 1215-1232. [Also available at https://doi.org/10.1007/s12237-014-9822-5.]
Neeson, T.M., Smith, S.D., Allan, J.D., and McIntyre, P.B., 2016, Prioritizing ecological restoration among sites in multi-stressor landscapes: Ecological Applications, v. 26, no. 6, p. 1785-1796. [Also available at https://doi.org/ 10.1890/15-0948.1.]

Pennings, S.C., and Bertness, M.D., 2001, Salt marsh communities, in Bertness, M.D., Gaines, S.D., and Hay, M.E., eds., Marine community ecology: Sunderland, Mass., Sinauer Associates, p. 289-316.

Perry, D.C., 2020, Salt marsh management-Monitoring threats and implementing climate adaptation initiatives [abs]: Kingston, University of Rhode Island, Ph.D. dissertation. Accessed May 20, 2020, at https://digitalcommon s.uri.edu/oa_diss/1160/.

Roman, C.T., 2017, Salt marsh sustainability_Challenges during an uncertain future: Estuaries and Coasts, v. 40, no. 3, p. 711-716. [Also available at https://doi.org/10.1007/ s12237-016-0149-2.]

Smith, J.A.M., 2013, The role of Phragmites australis in mediating inland salt marsh migration in a mid-Atlanic estuary: PLoS One, v. 8, no. 5, e65091. [Also available at https://doi.org/10.1371/journal.pone.0065091.]

Steinkamp, M., 2008, New England/mid-Atlantic coast bird conservation (BCR 30) implementation plan: Atlantic Coast Joint Venture, 251 p., accessed August 15, 2018, at https://www.acjv.org/BCR_30/BCR30_June_23_2008_ final.pdf.

U.S. Fish and Wildlife Service [FWS], 2004, Edwin B. Forsythe National Wildlife Refuge-Comprehensive conservation plan: U.S. Fish and Wildlife Service, 209 p., accessed May 20, 2020, at https://www.fws.gov/refuge/ Edwin_B_Forsythe/what_we_do/finalccp.html.

U.S. Fish and Wildlife Service [FWS], 2013, Edwin B. Forsythe National Wildlife Refuge draft habitat management plan: U.S. Fish and Wildlife Service, 141 p., accessed May 20, 2020, at https://www.fws.gov/refuge/Edwin_B_ Forsythe/what_we_do/HMPdraft.html.

U.S. North American Bird Conservation Initiative, 2020, Bird conservation regions: U.S. North American Bird Conservation Initiative web page, accessed July 6, 2020, at https://nabci-us.org/resources/bird-conservation-regions/.

Wigand, C., Ardito, T., Chaffee, C., Ferguson, W., Paton, S., Raposa, K., Vandemoer, C., and Watson, E., 2017, A climate change adaptation strategy for management of coastal marsh systems: Estuaries and Coasts, v. 40, no. 3, p. 682-693. [Also available at https://doi.org/10.1007/ s12237-015-0003-y.] 

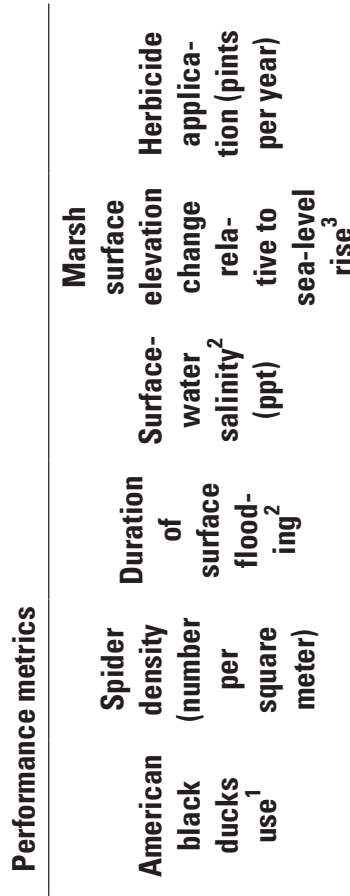

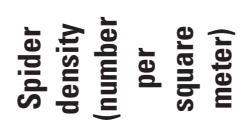

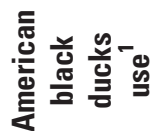

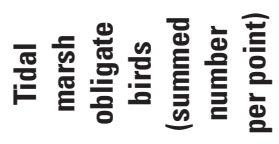

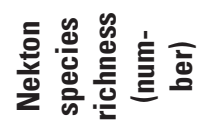

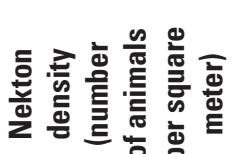

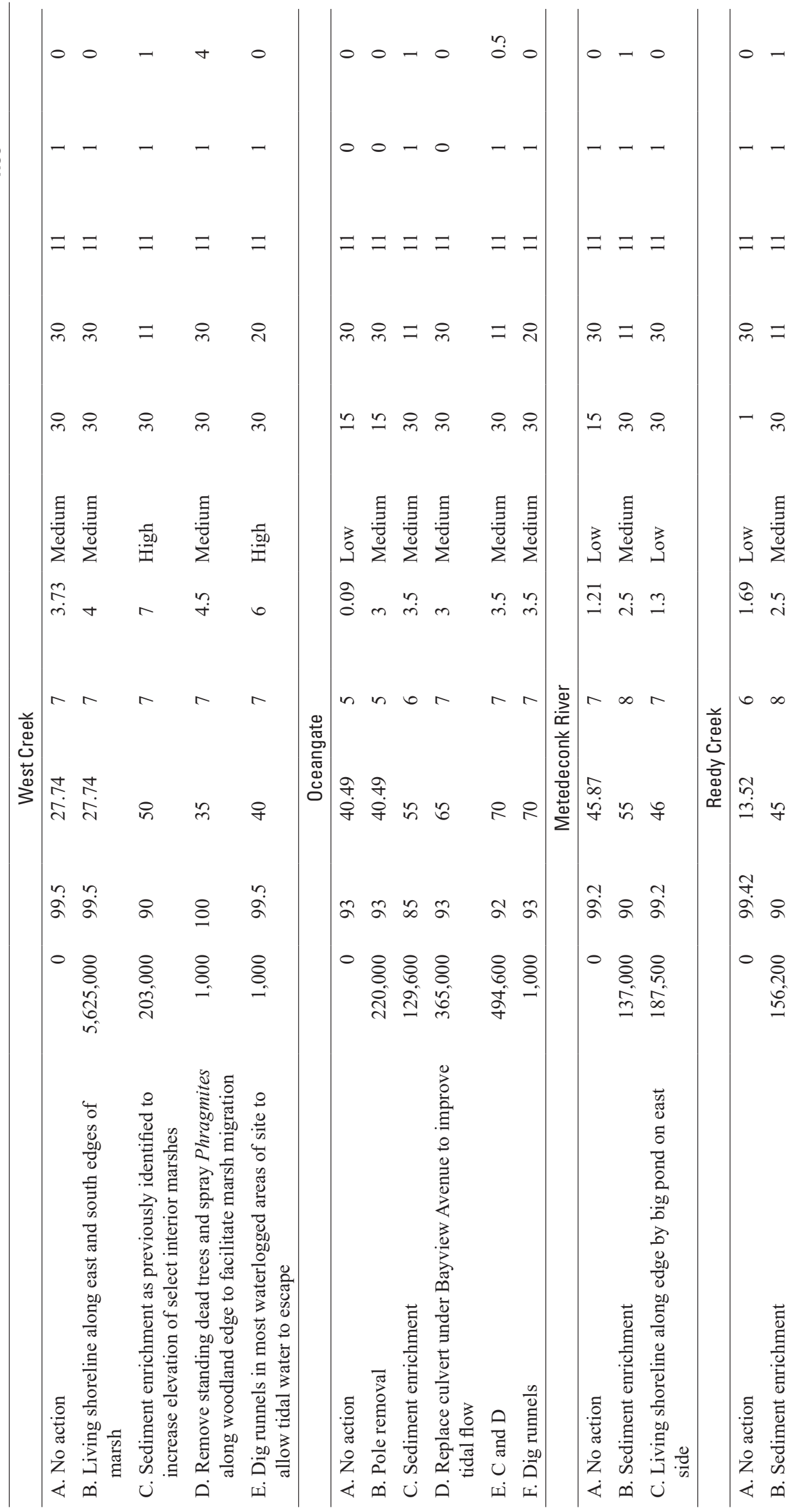

兽

क्

总密离

象

. 总

$\frac{0}{2} \frac{\pi}{0}$

옹

.

흥

象

음

至

텅

음

䒕 을

$\frac{0}{\bar{c}}$

垔

की เก

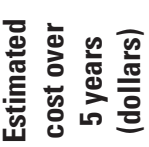

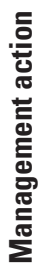




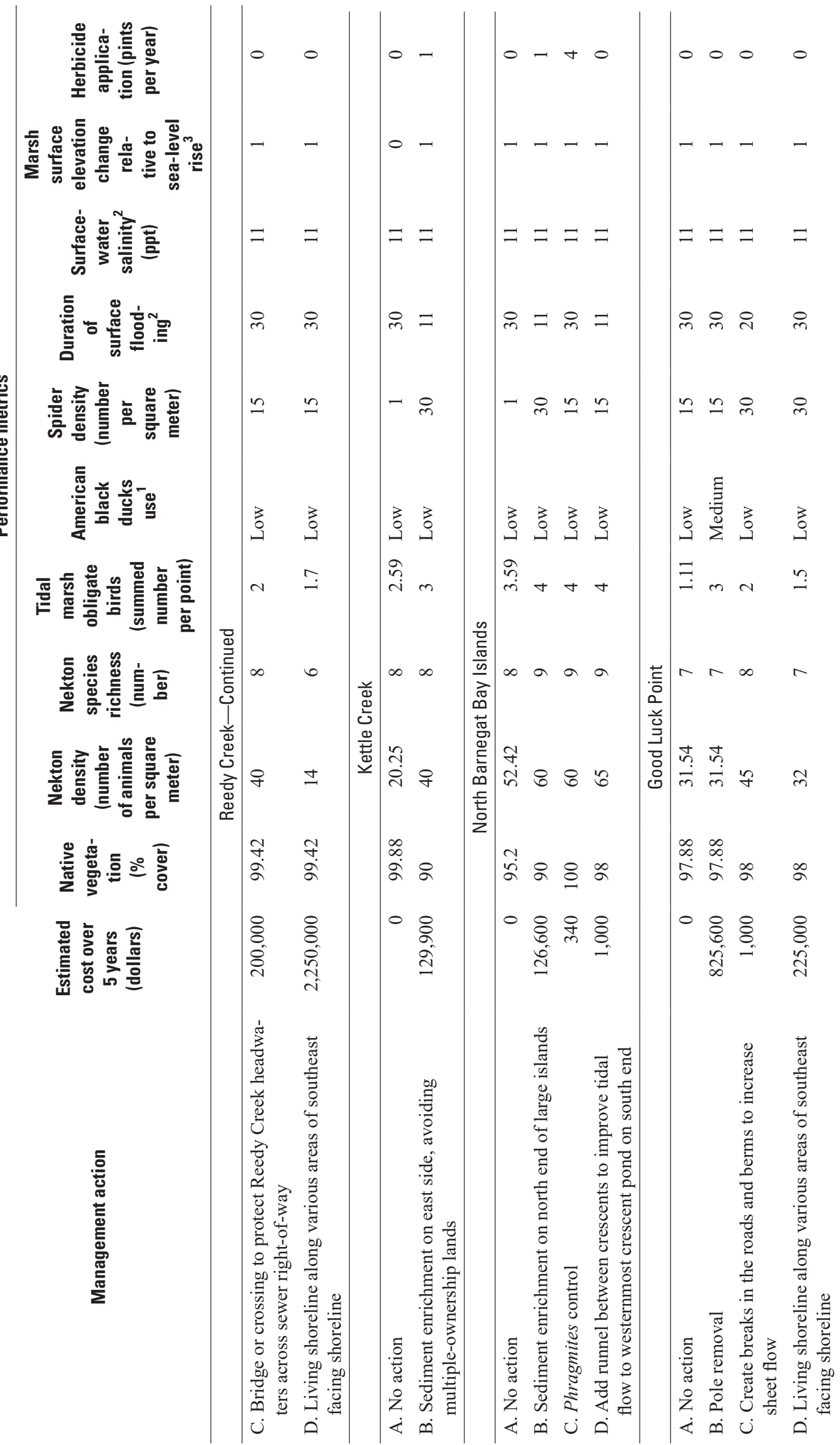



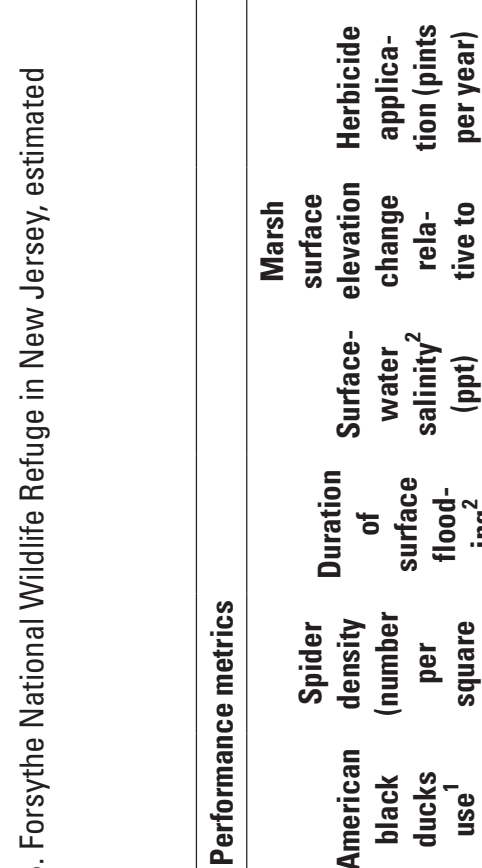

들

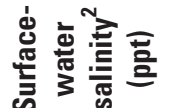

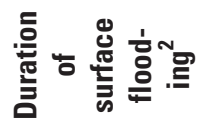

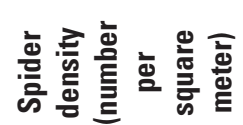

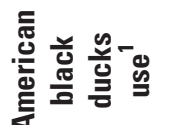

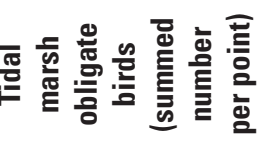

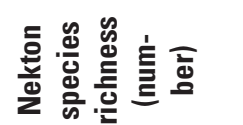

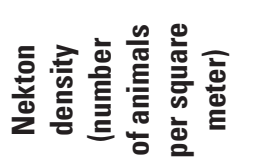
宽悹

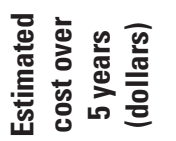

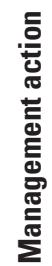

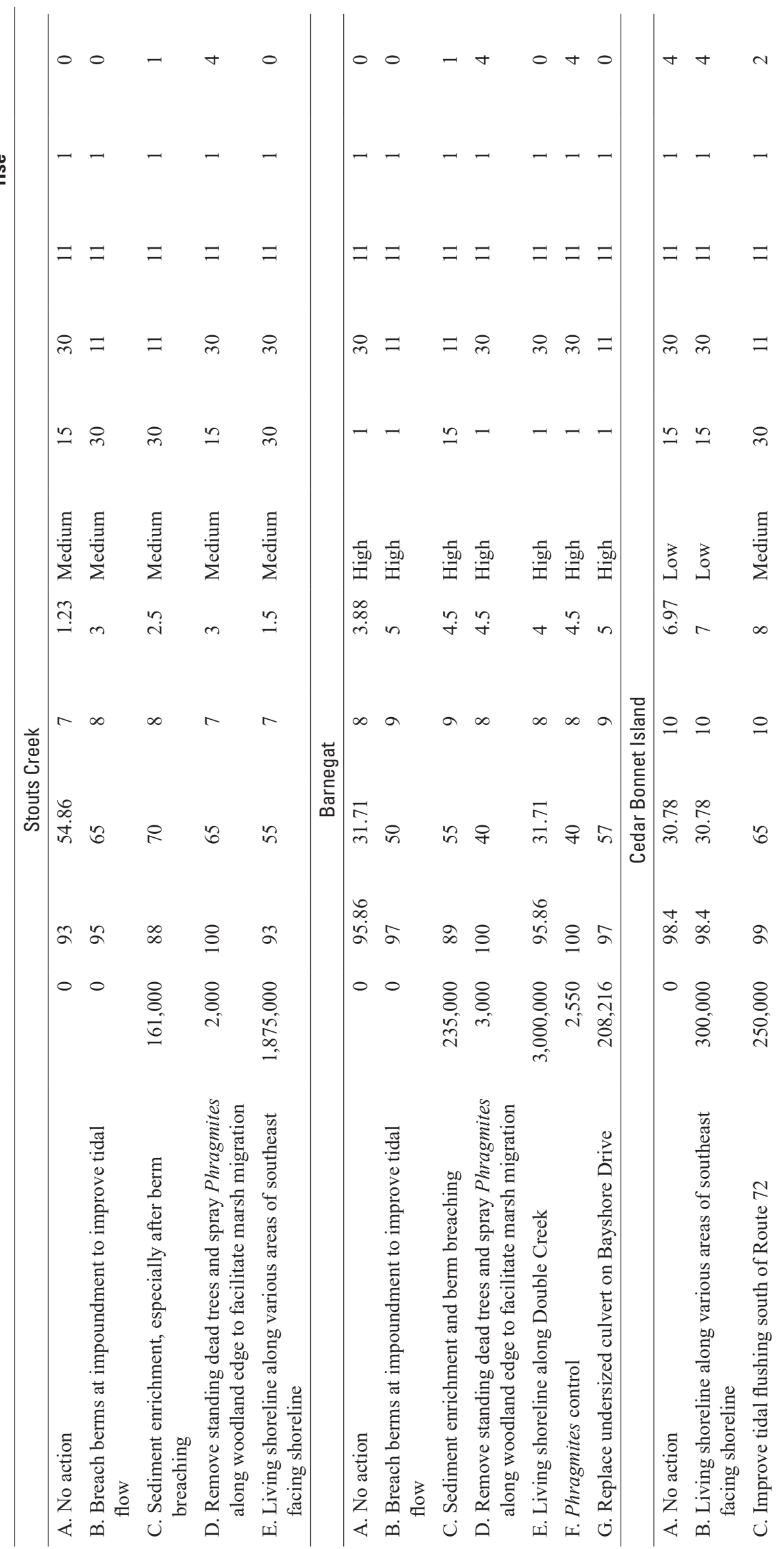




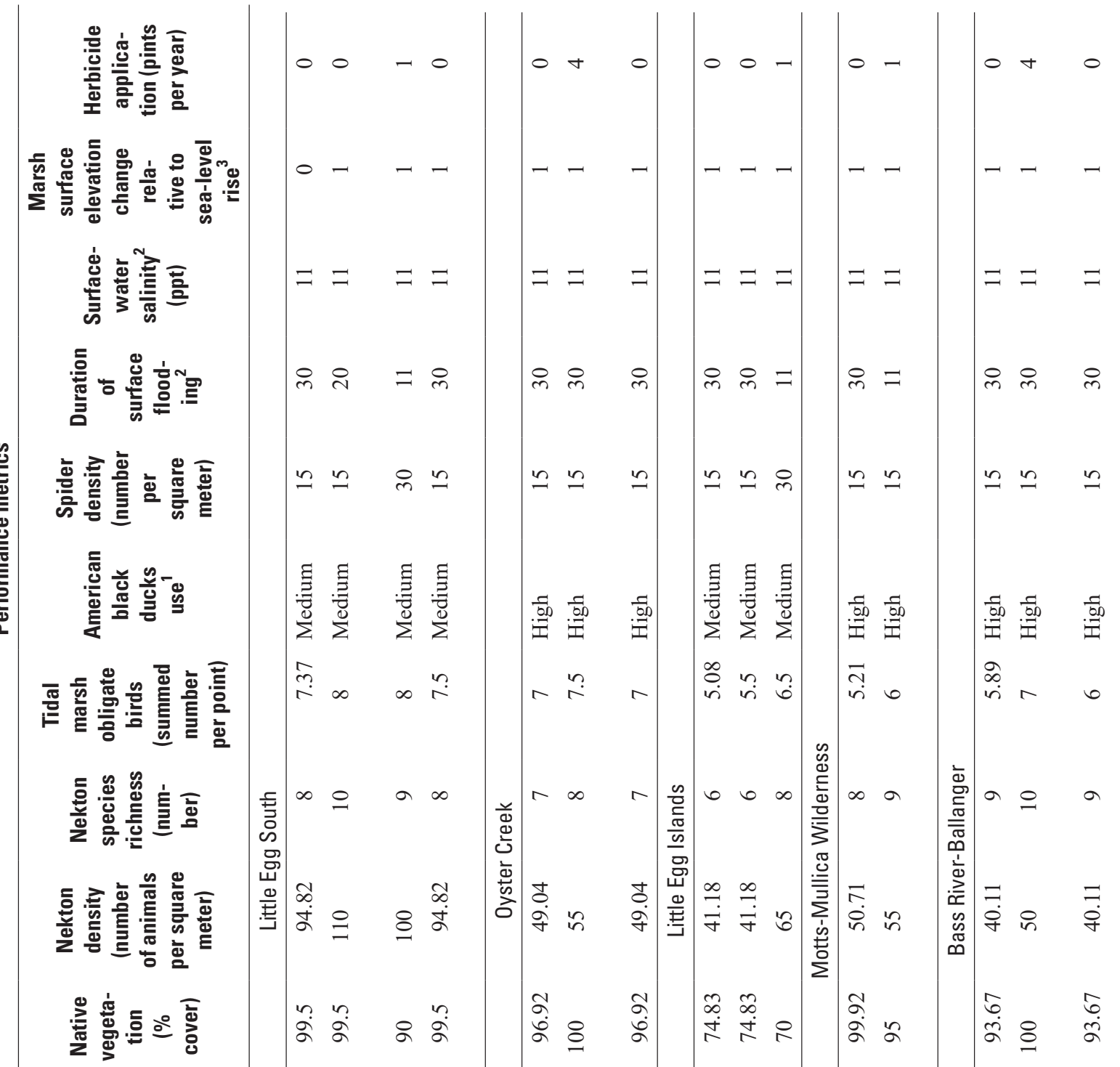

衰志

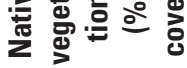

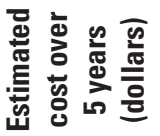

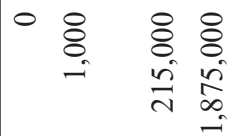

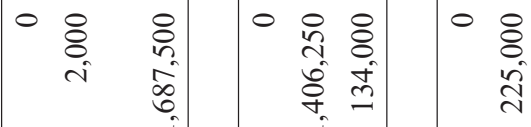

$\begin{array}{ll}0 & 8 \\ 0 & 8 \\ i & 0 \\ 1 & 0 \\ & 0\end{array}$

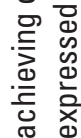

흔

资

등

등

च

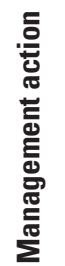

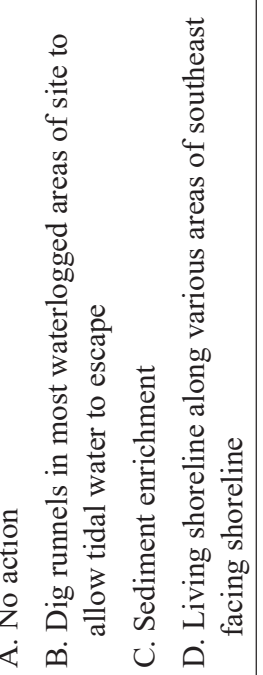

列

초유.

咅

窟

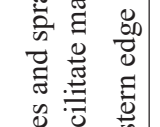

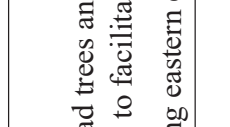

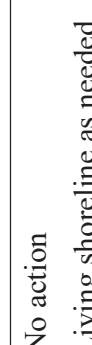

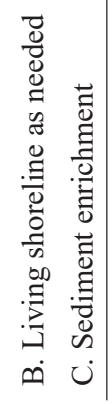

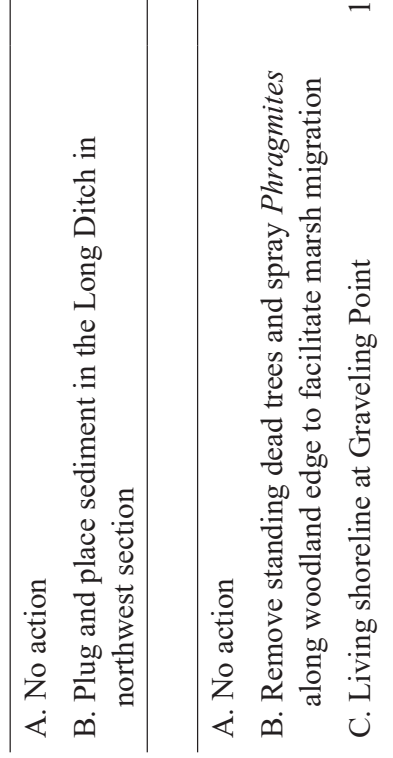




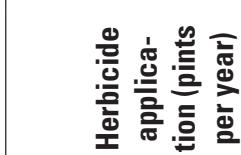

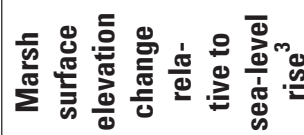

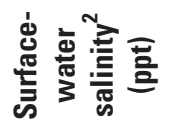

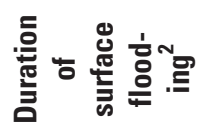

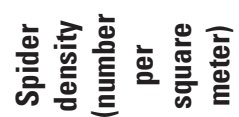

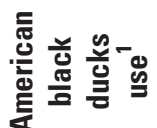

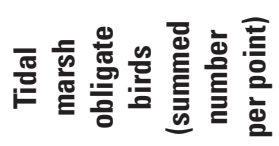

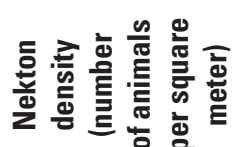
悹离

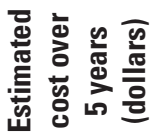

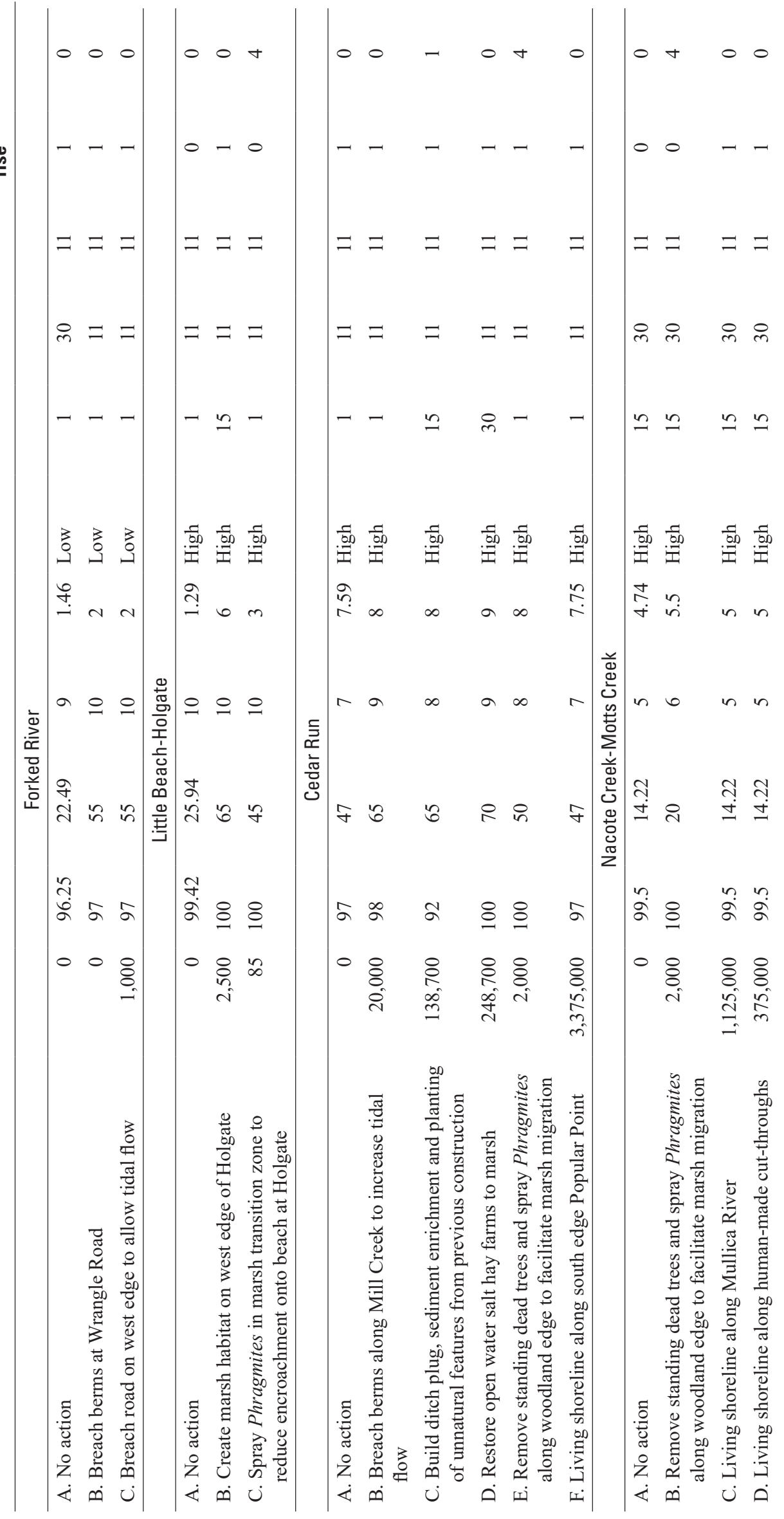




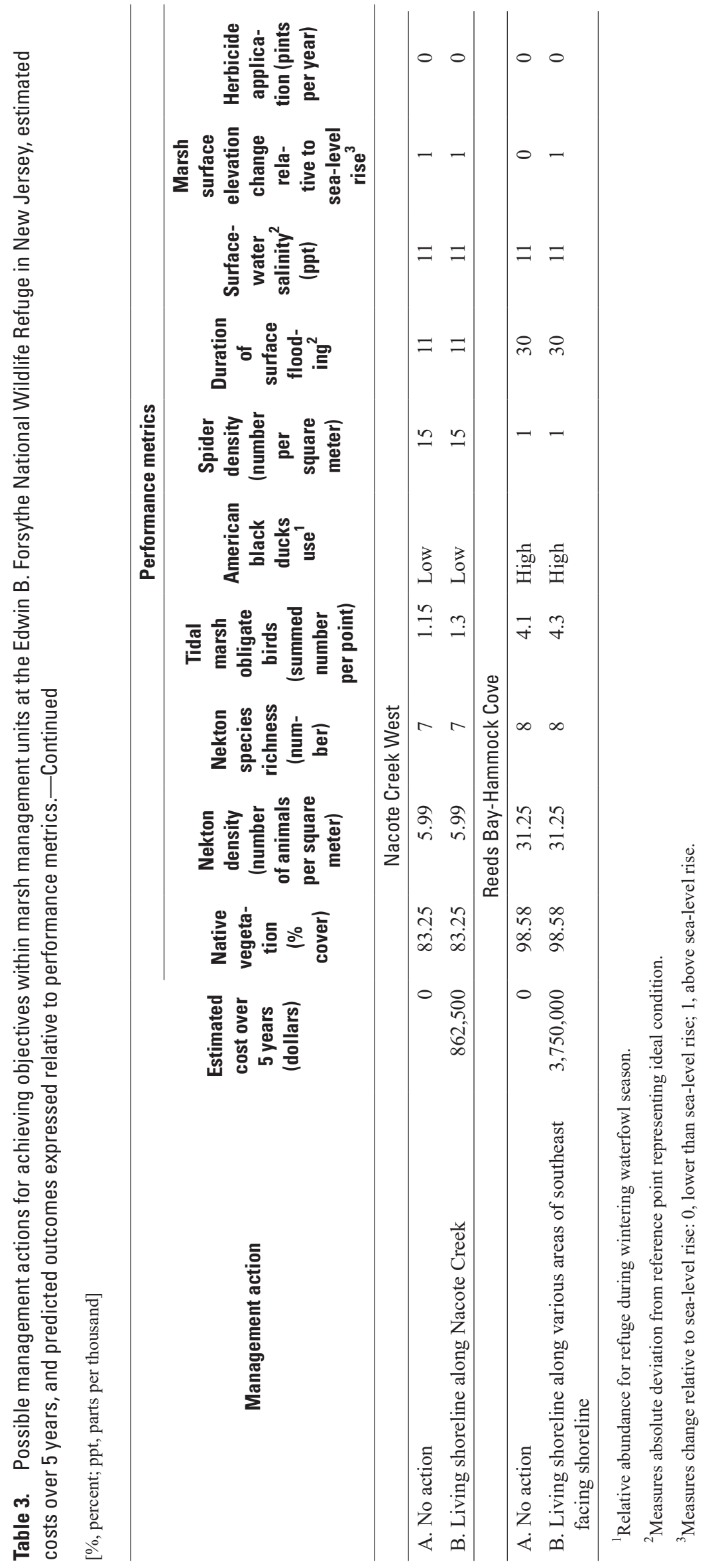




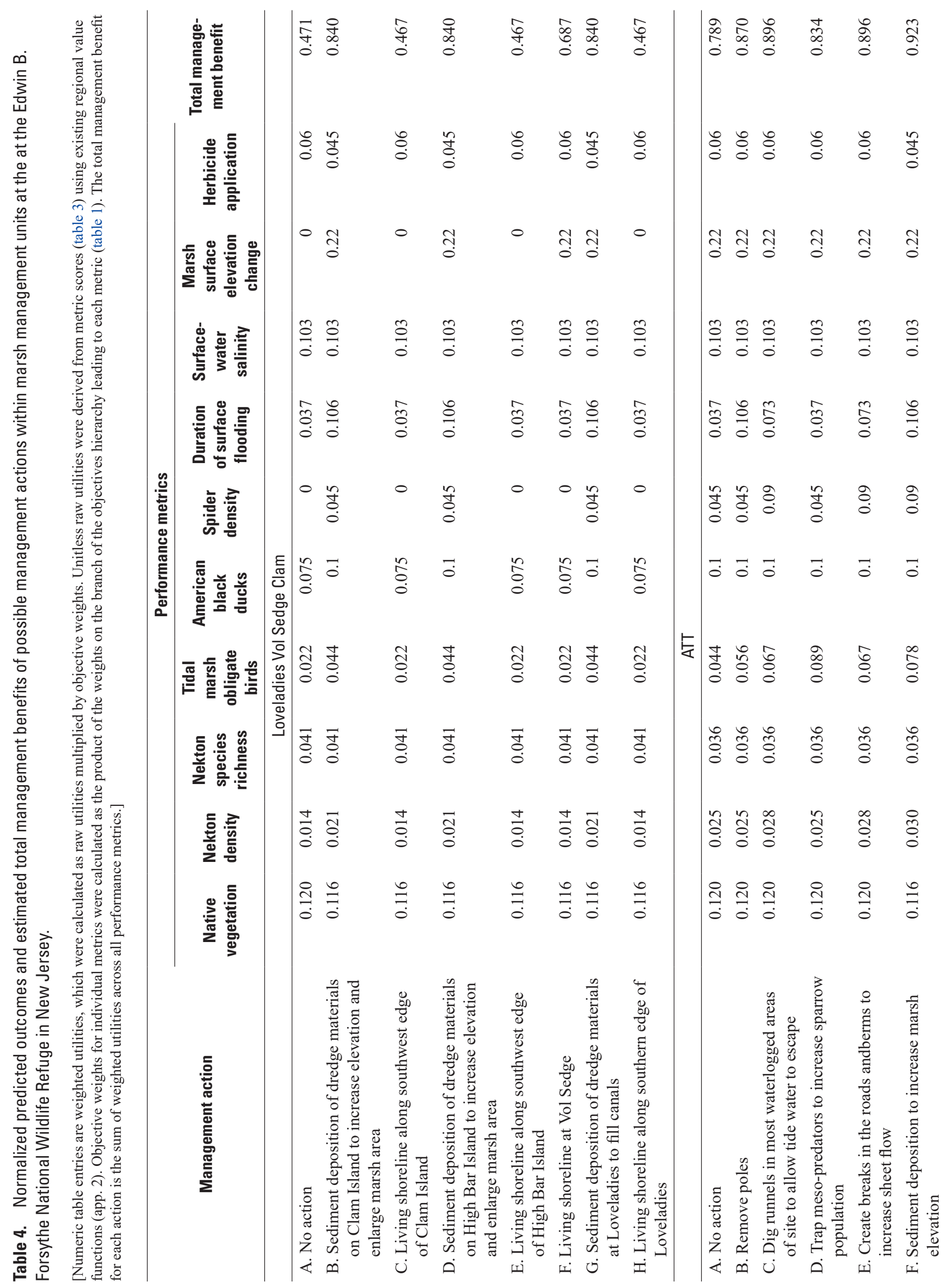




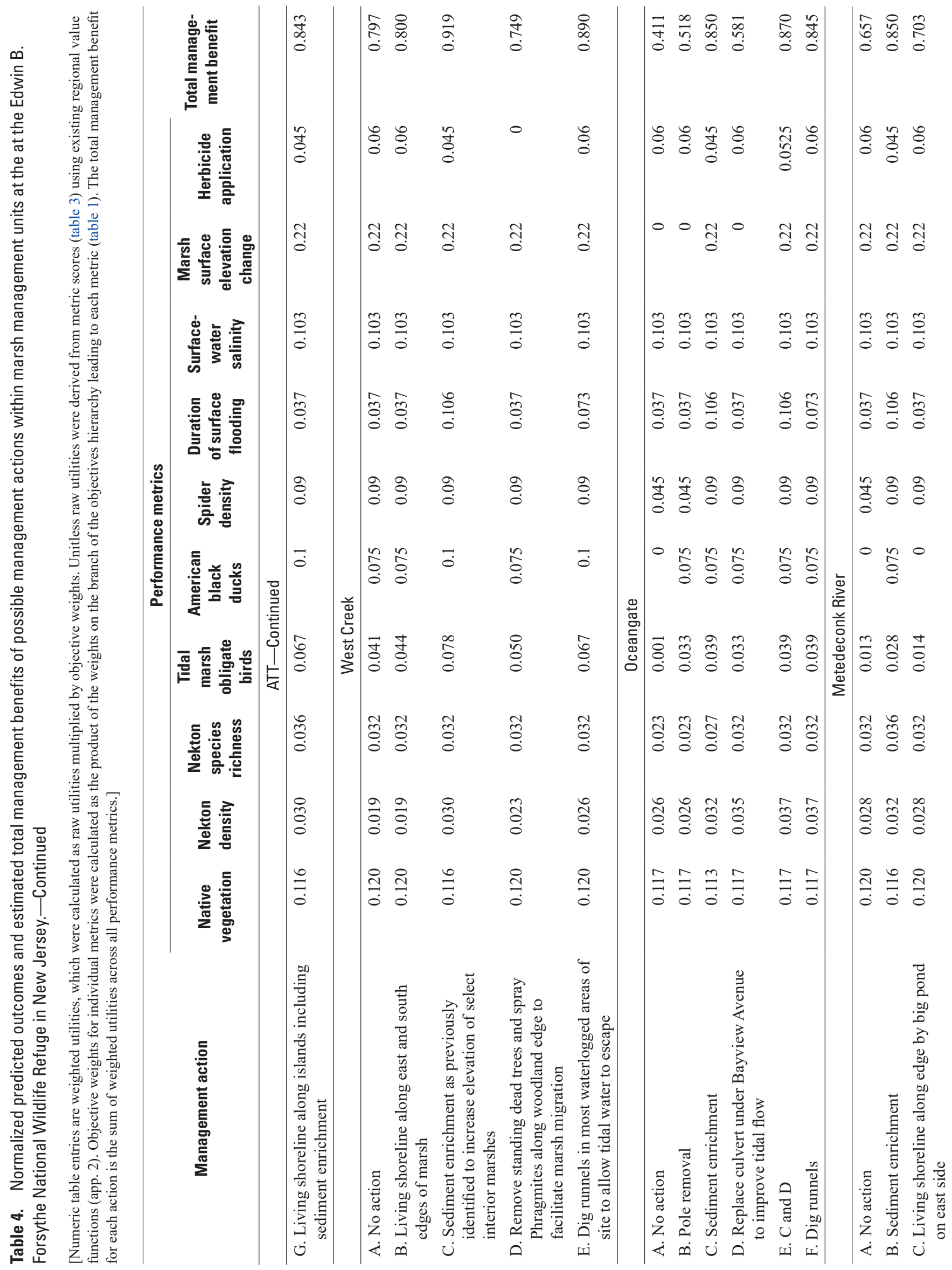




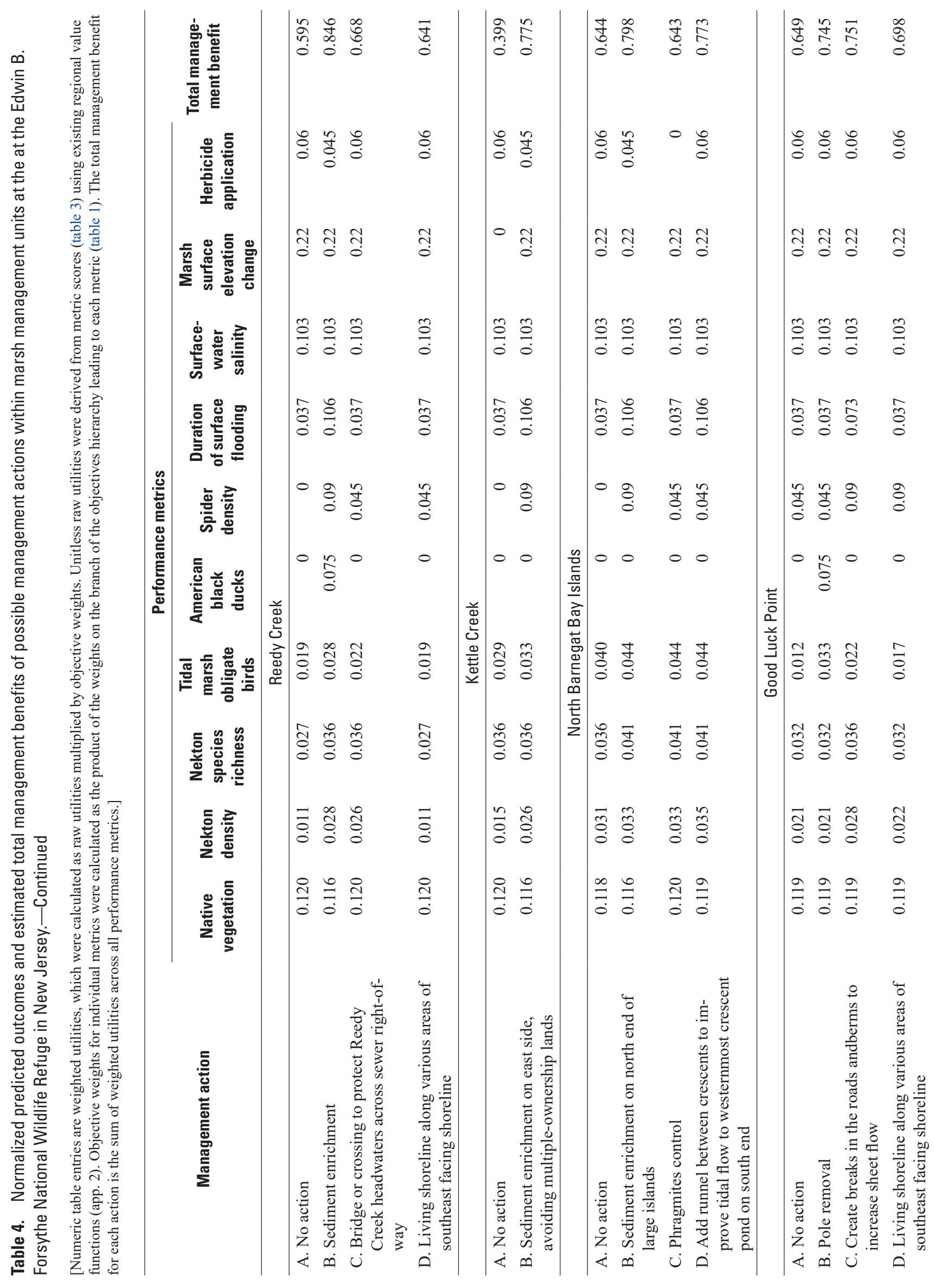




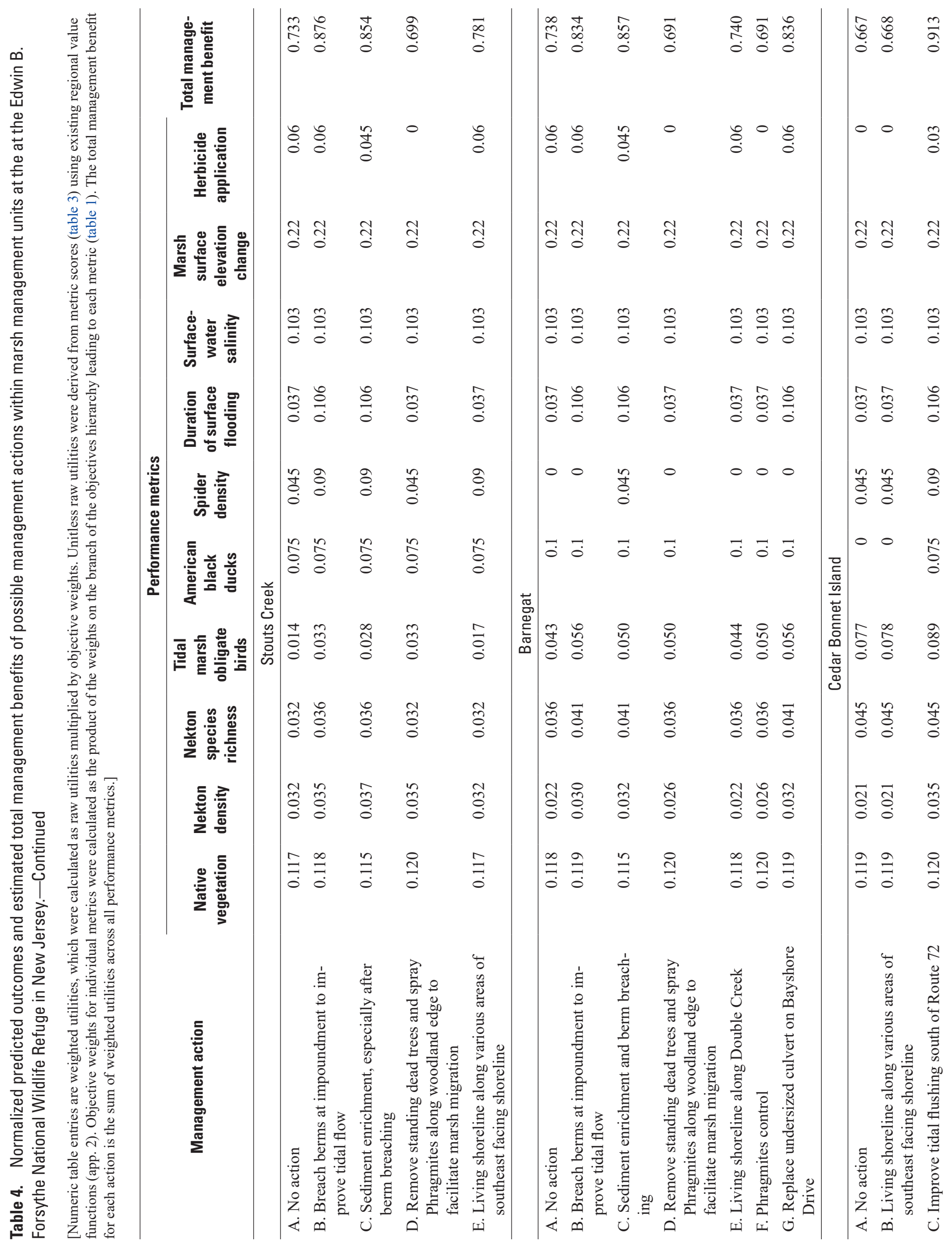




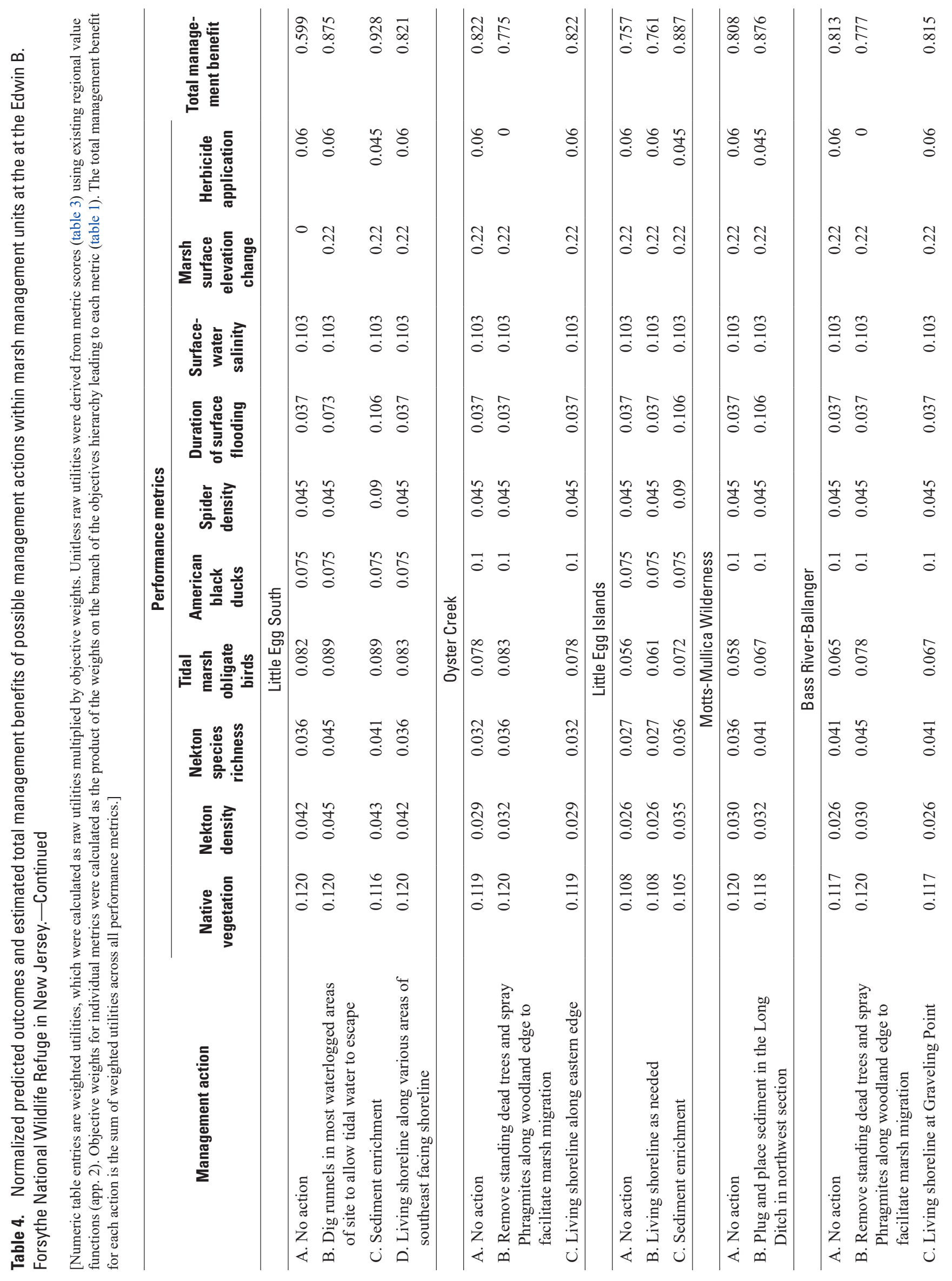




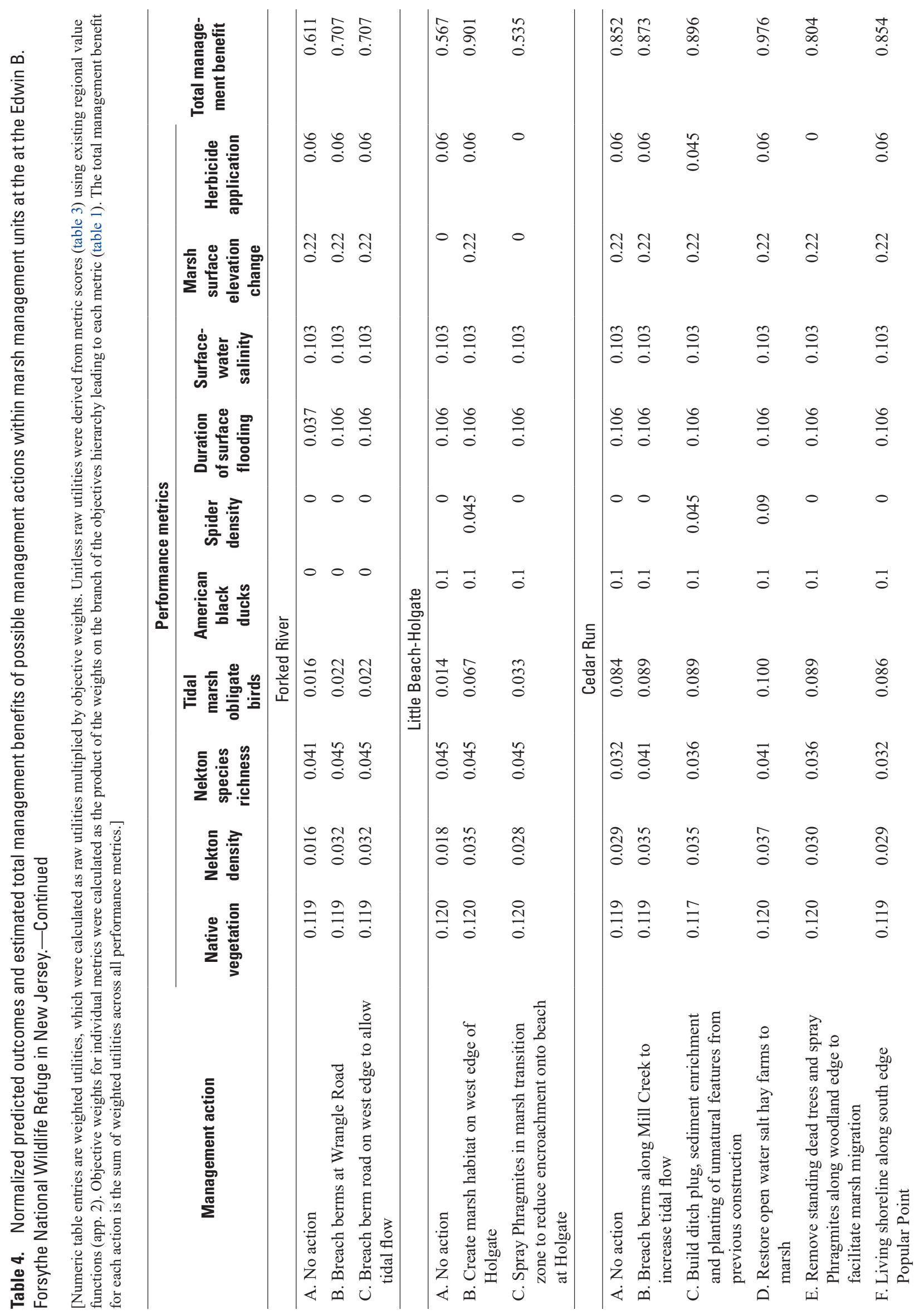




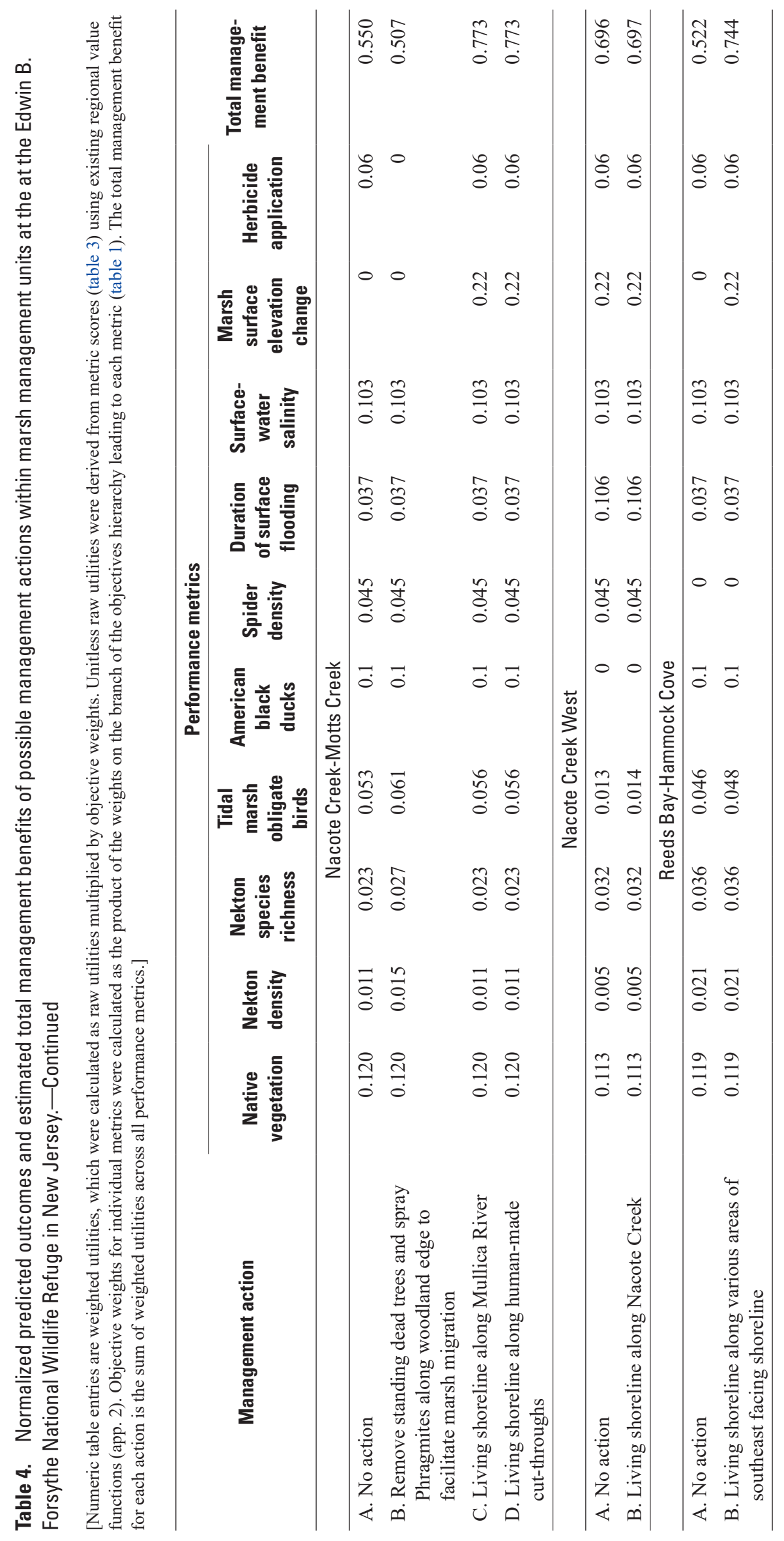




\section{Appendix 1. Regional Influence Diagrams}

The influence diagrams (following the style of prototype diagrams in Neckles and others, 2015) in this appendix (figs. 1.1-1.8) relate possible management strategies to performance metrics. Shapes represent elements of decisions, as follows: rectangles for actions, rectangles with rounded corners for deterministic factors, ovals for stochastic events, and hexagons for consequences expressed as a performance metric.

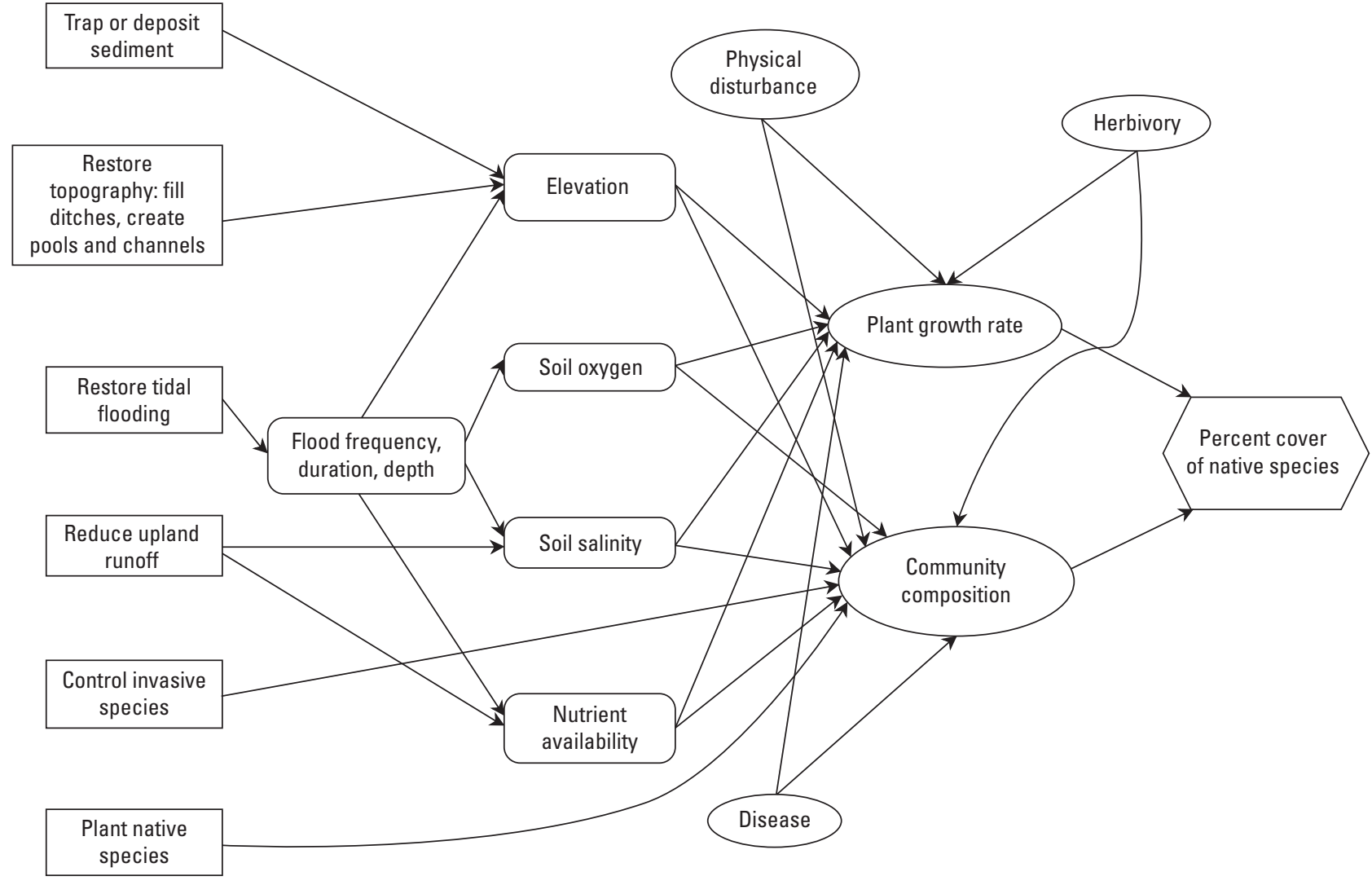

Figure 1.1. Influence diagram used to estimate percent cover of native vegetation in response to implementing certain management actions. 


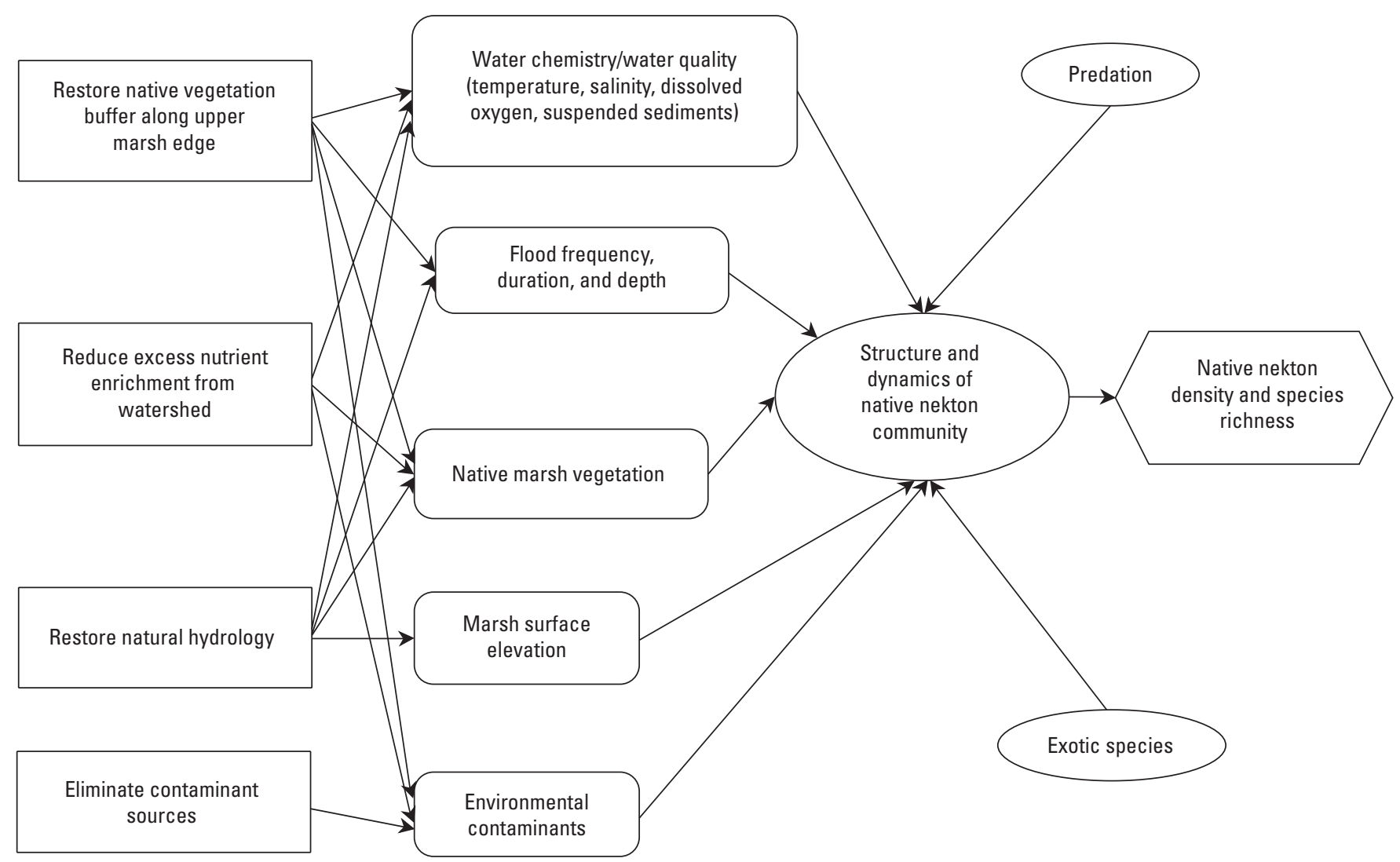

Figure 1.2. Influence diagram used to estimate nekton density and species richness in response to implementing certain management actions. 


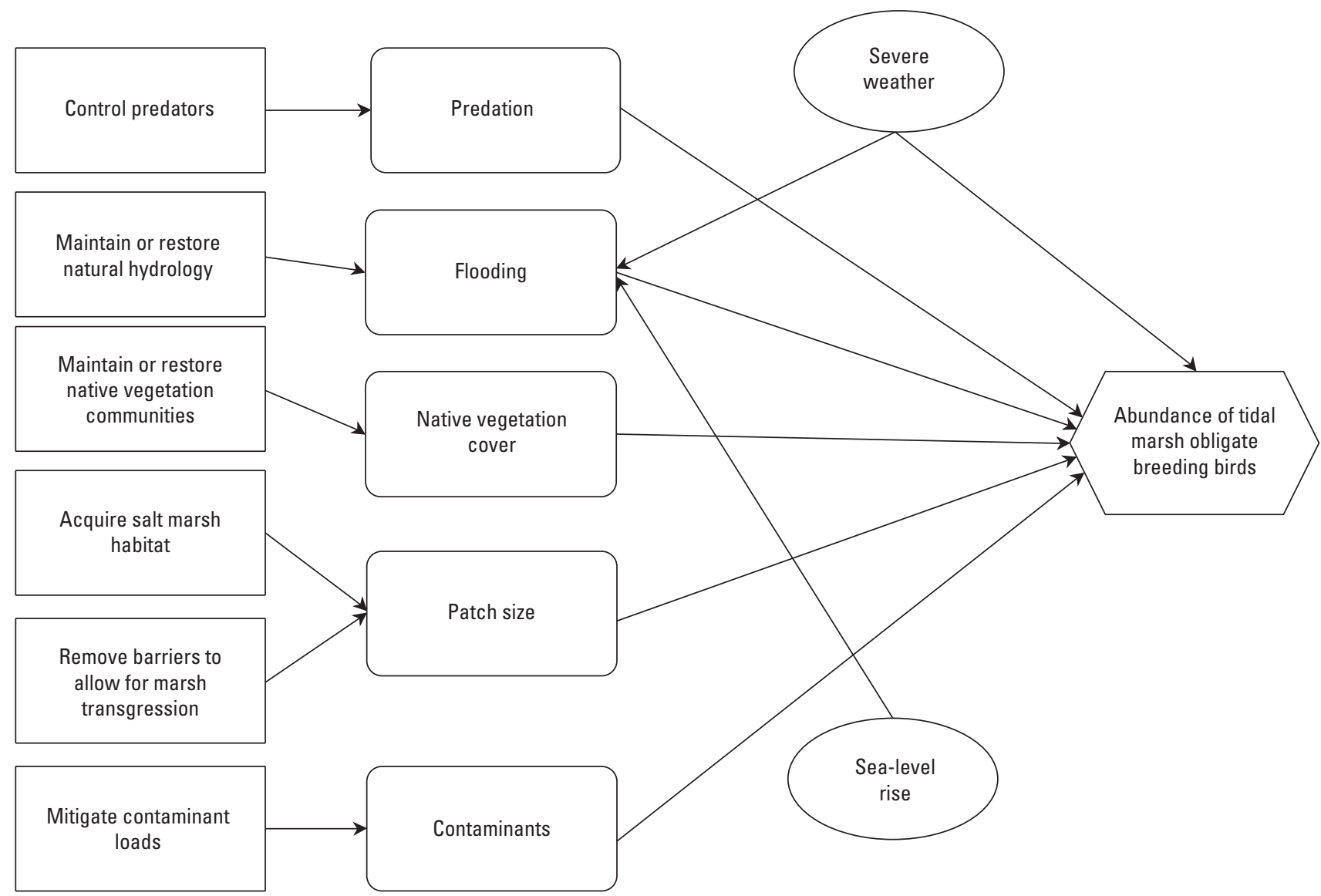

Figure 1.3. Influence diagram used to estimate abundance of tidal marsh obligate breeding birds in response to implementing certain management actions. 


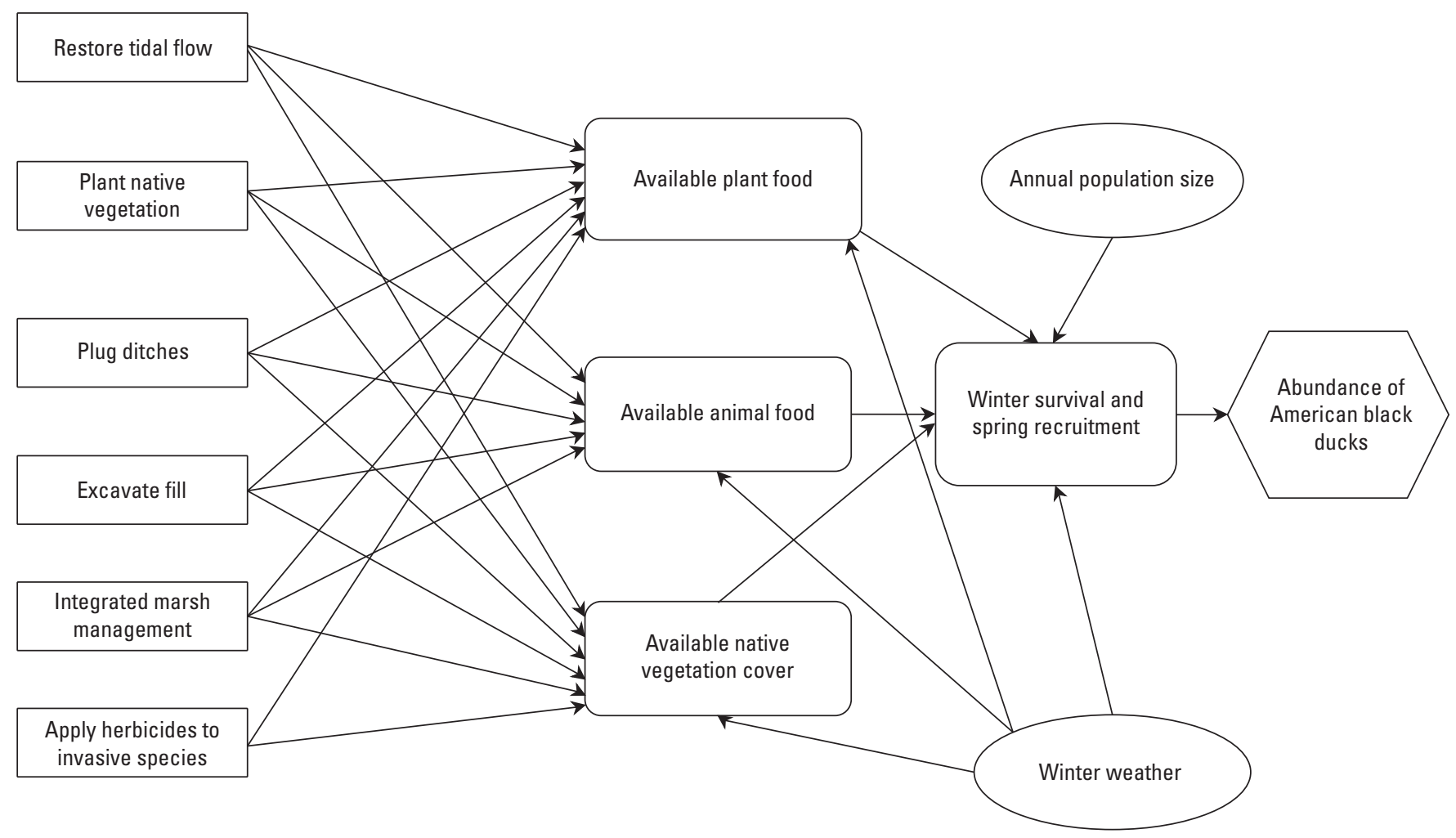

Figure 1.4. Influence diagram used to estimate abundance of American black ducks in winter, as indicator species for nonbreeding wetland birds, in response to implementing certain management actions. 


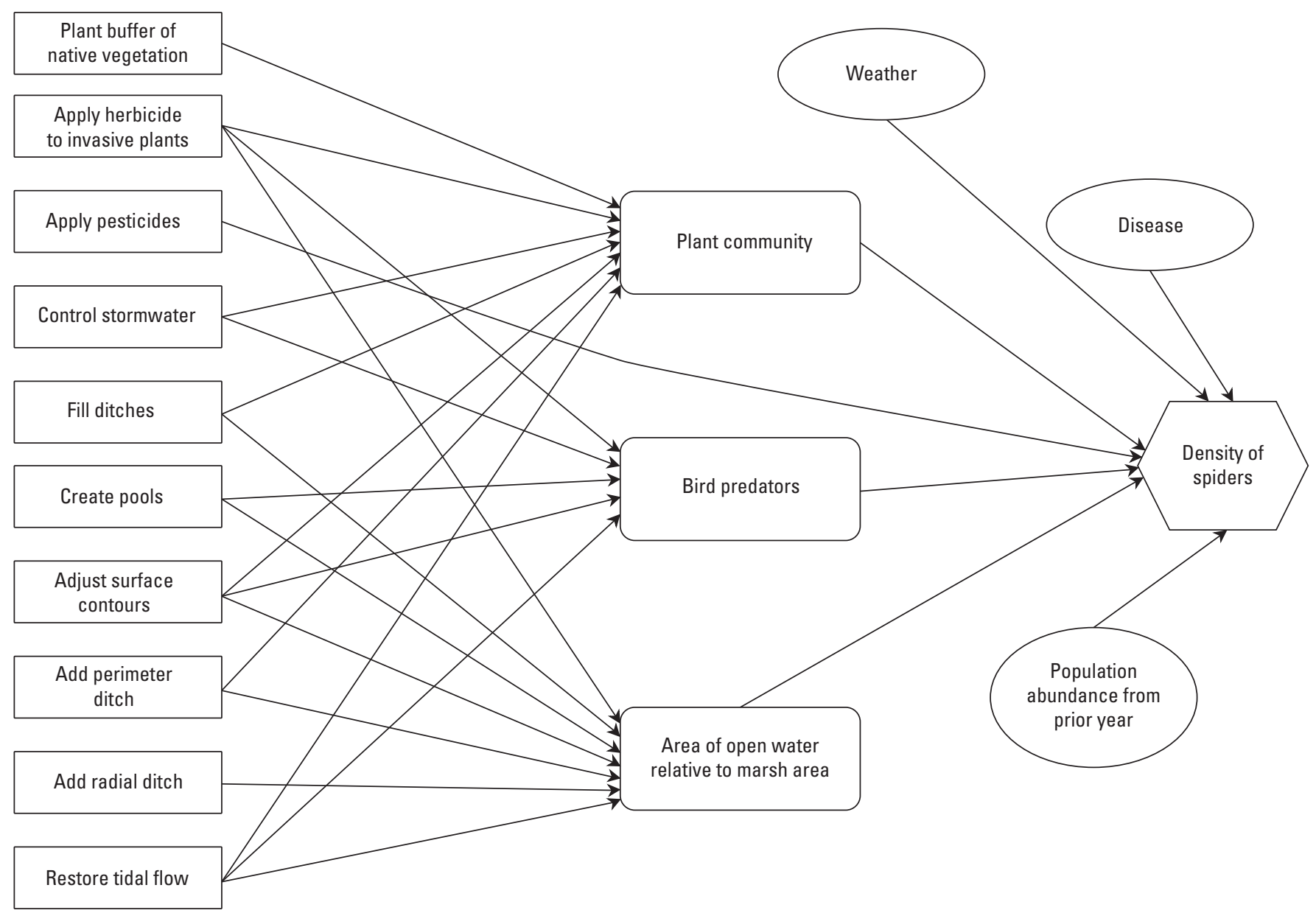

Figure 1.5. Influence diagram used to estimate density of spiders, as indicator of trophic health, in response to implementing certain management actions. 


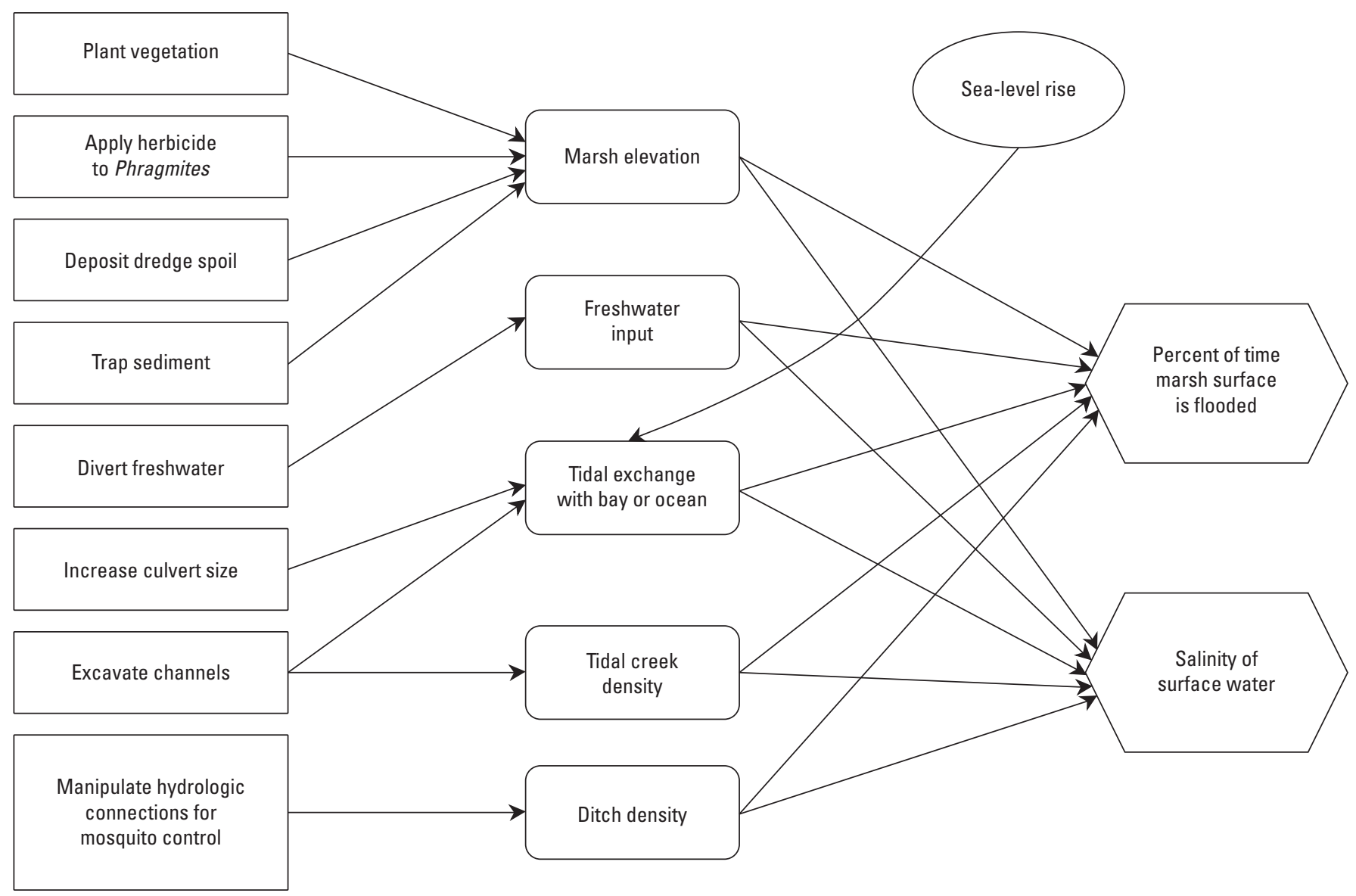

Figure 1.6. Influence diagram used to estimate percent of time marsh surface is flooded and salinity of marsh surface water in response to implementing certain management actions. 


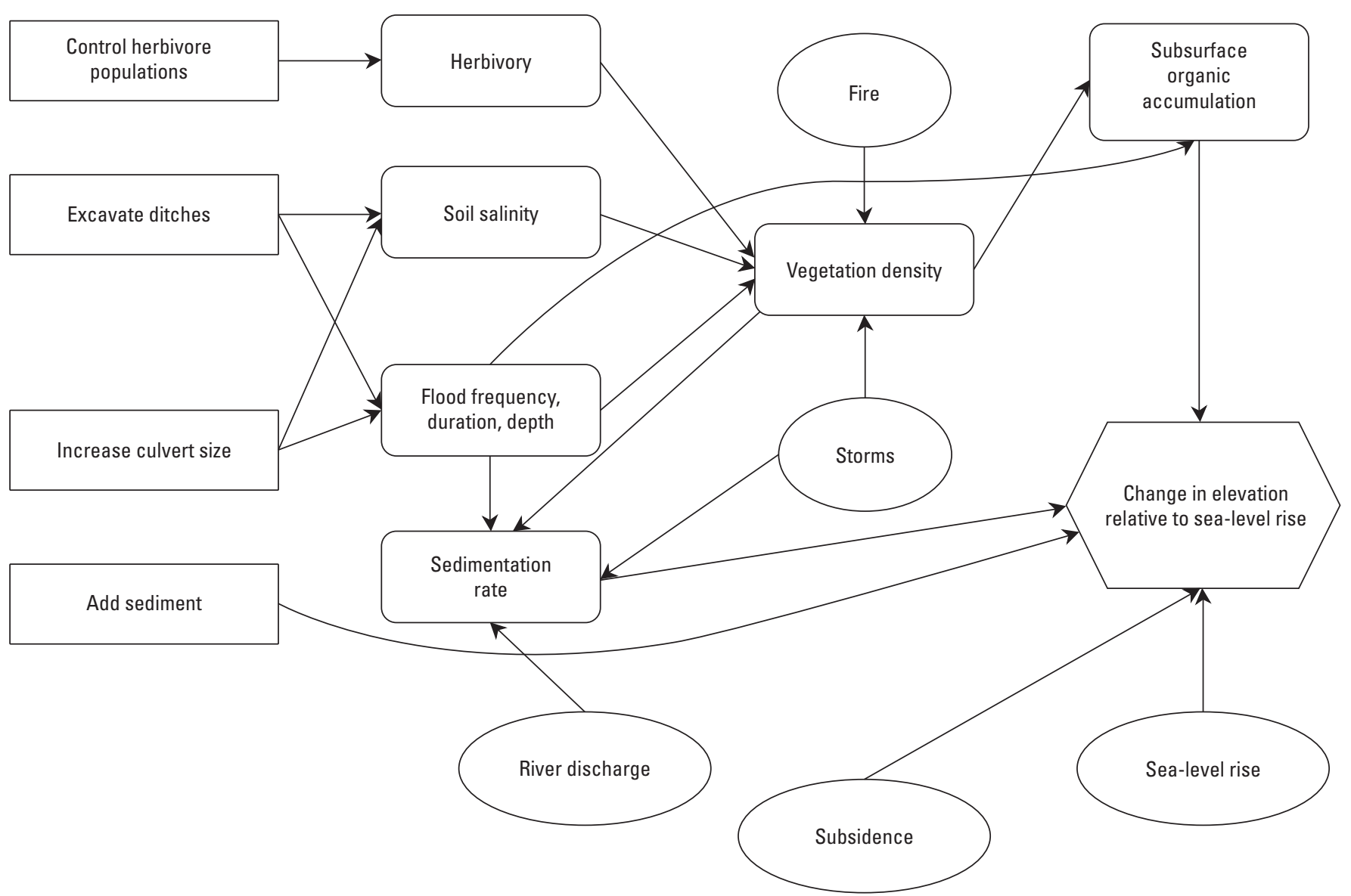

Figure 1.7. Influence diagram used to estimate change in elevation of the marsh surface relative to sea-level rise in response to implementing certain management actions.

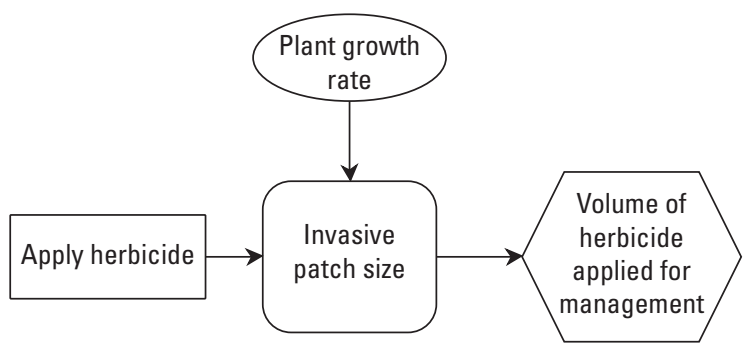

Figure 1.8. Influence diagram used to estimate volume of herbicide that could be applied if a decision was made to use chemical control for removing unwanted vegetation.

\section{Reference Cited}

Neckles, H.A., Lyons, J.E., Guntenspergen, G.R., Shriver, W.G., and Adamowicz, S.C., 2015, Use of structured decision making to identify monitoring variables and management priorities for salt marsh ecosystems: Estuaries and Coasts, v. 38, no. 4, p. 1215-1232. [Also available at https://doi.org/10.1007/s12237-014-9822-5.] 


\section{Appendix 2. Utility Functions for the Edwin B. Forsythe National Wildlife Refuge}

Utilities $[u(x)]$ are derived as monotonically increasing, monotonically decreasing, or step functions over the range of performance metric $x$. In the functions in figures 2.1 to 2.10 , $\mathrm{x}$, Low, High, and $\rho$ are expressed in performance metric units; Low and High represent the endpoints of the given metric range for the Edwin B. Forsythe National Wildlife Refuge; and $\rho$ represents a shape parameter derived by stakeholder elicitation (Neckles and others, 2015). Break points in step functions were also derived by stakeholder elicitation.

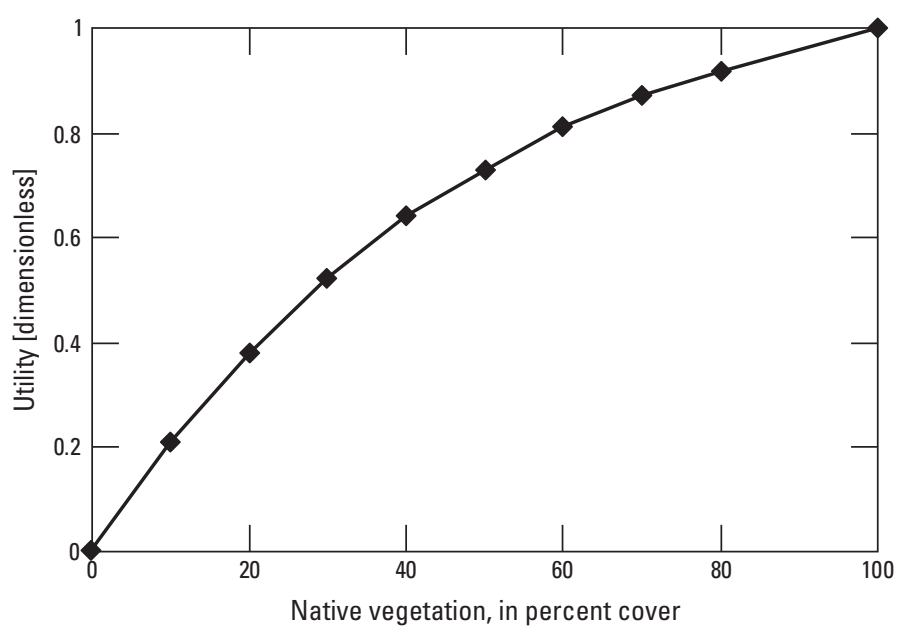

$$
\begin{aligned}
u(x) & =\frac{1-e^{\frac{-(x-\text { Low })}{\rho}}}{1-e^{\frac{-(\text { High-Low })}{\rho}}} \\
\text { where } & \\
\text { Low } & =0 \\
\text { High } & =100 \\
\rho & =50
\end{aligned}
$$

Figure 2.1. Native vegetation at the Edwin B. Forsythe National Wildlife Refuge, New Jersey.

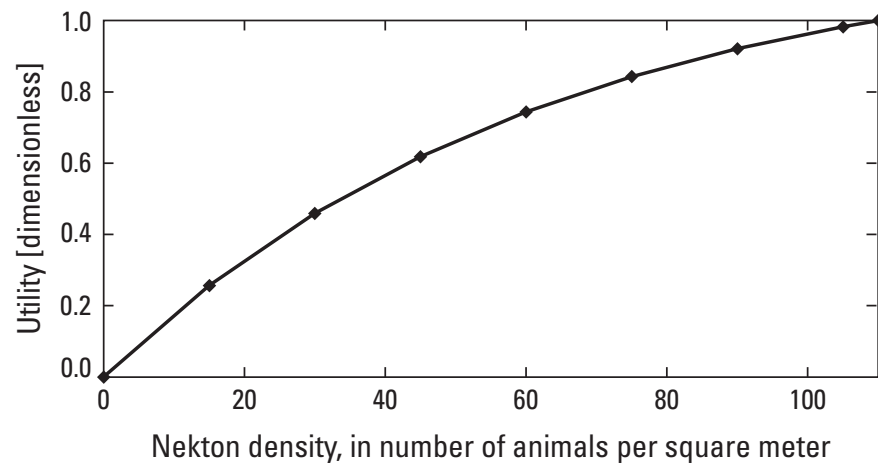

$$
\begin{aligned}
u(x) & =\frac{1-e^{\frac{-(x-\text { Low })}{\rho}}}{1-e^{\frac{-(\text { High-Low })}{\rho}}} \\
\text { where } & \\
\text { Low } & =0 \\
\text { High } & =110 \\
\rho & =63
\end{aligned}
$$

Figure 2.2. Native nekton density at the Edwin B. Forsythe National Wildlife Refuge, New Jersey. 


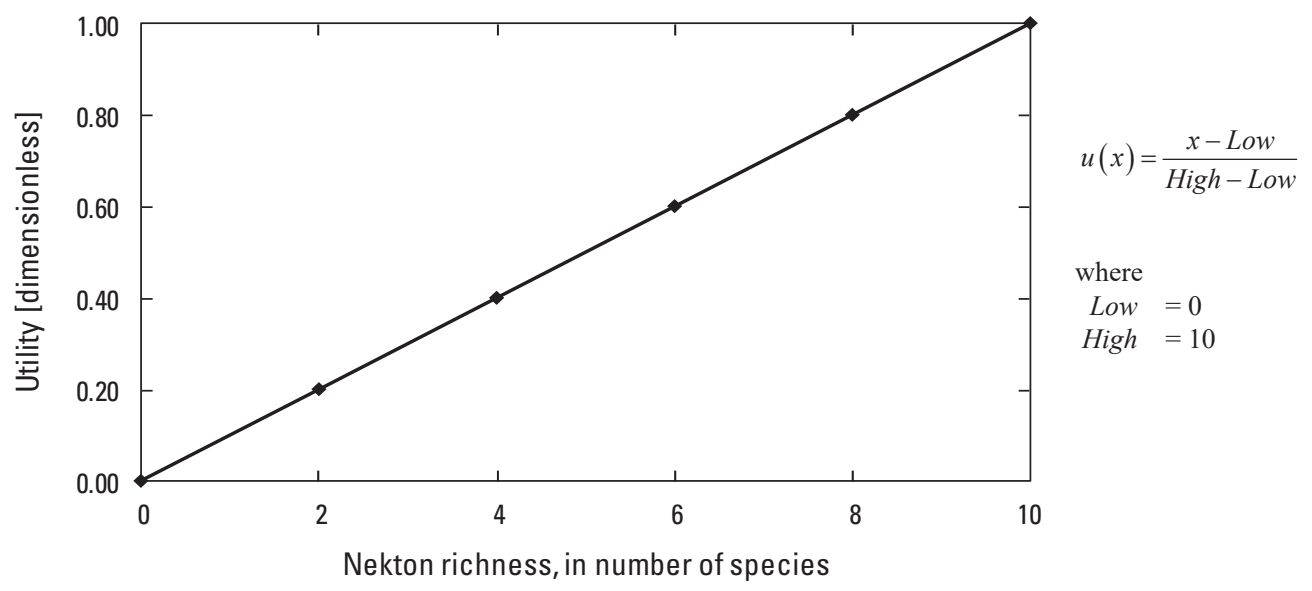

Figure 2.3. Native nekton species richness at the Edwin B. Forsythe National Wildlife Refuge, New Jersey.

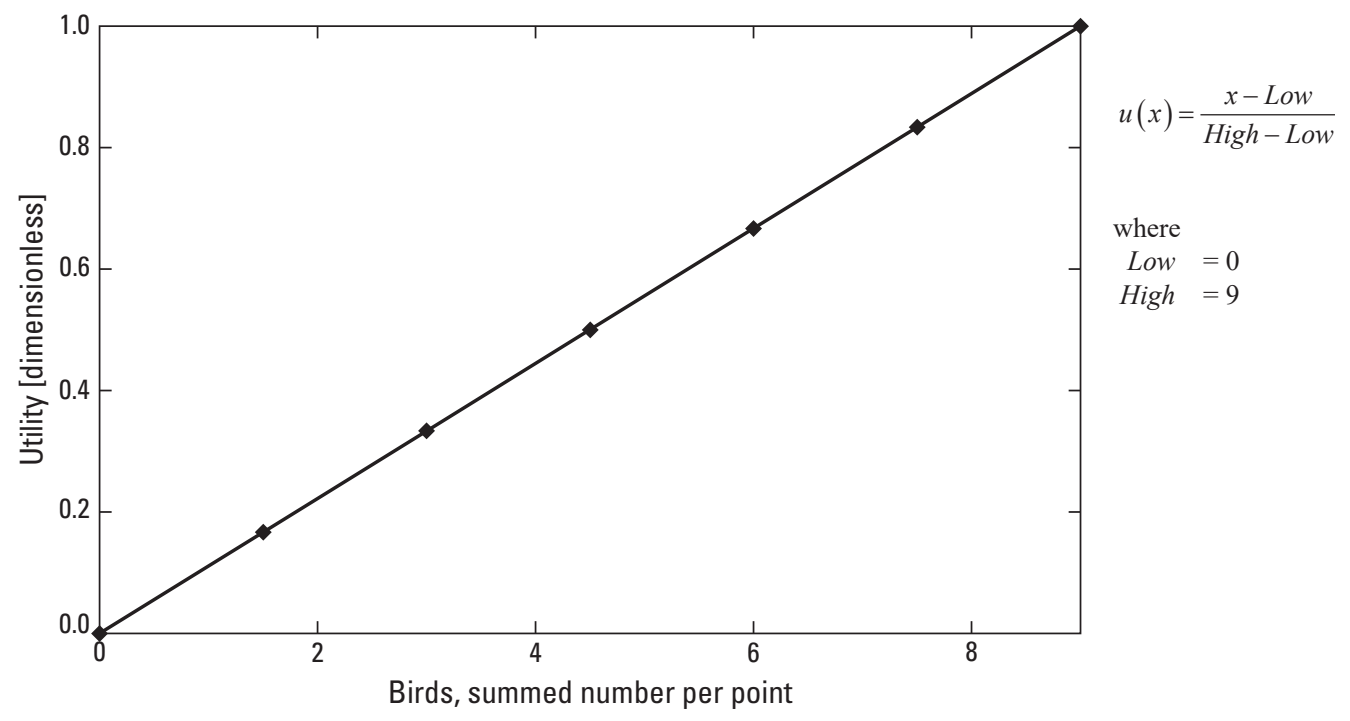

Figure 2.4. Tidal marsh obligate birds at the Edwin B. Forsythe National Wildlife Refuge, New Jersey.

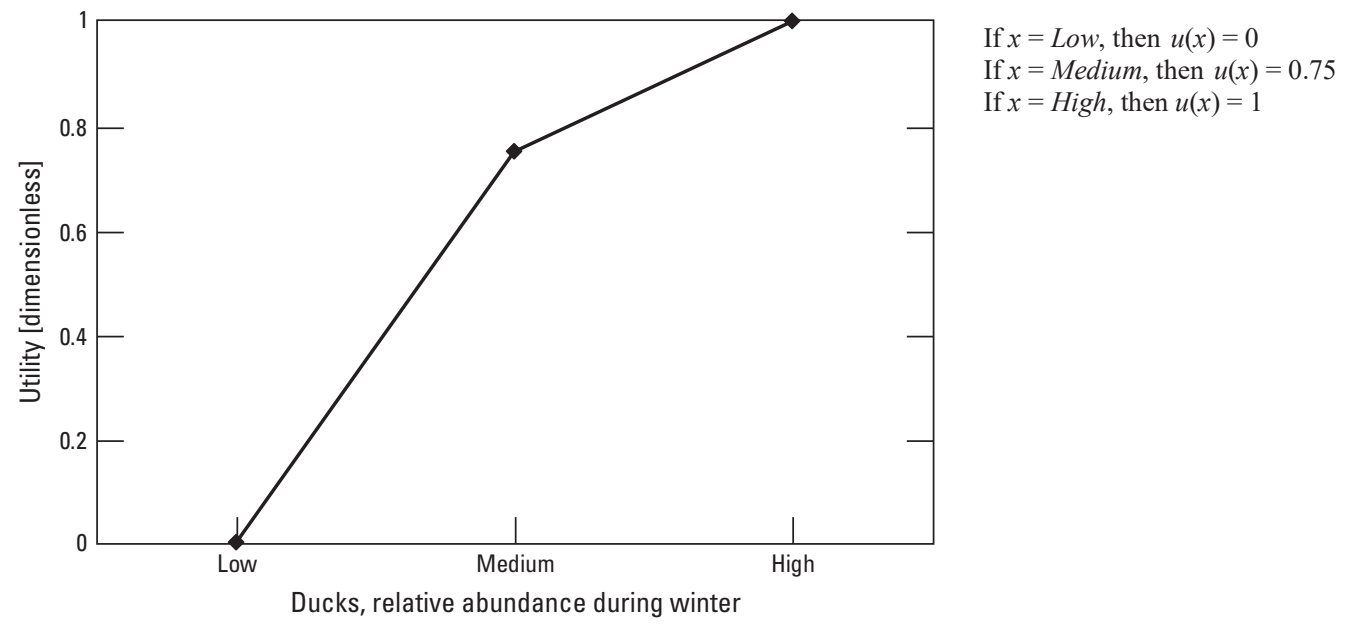

Figure 2.5. American black ducks at the Edwin B. Forsythe National Wildlife Refuge, New Jersey. 


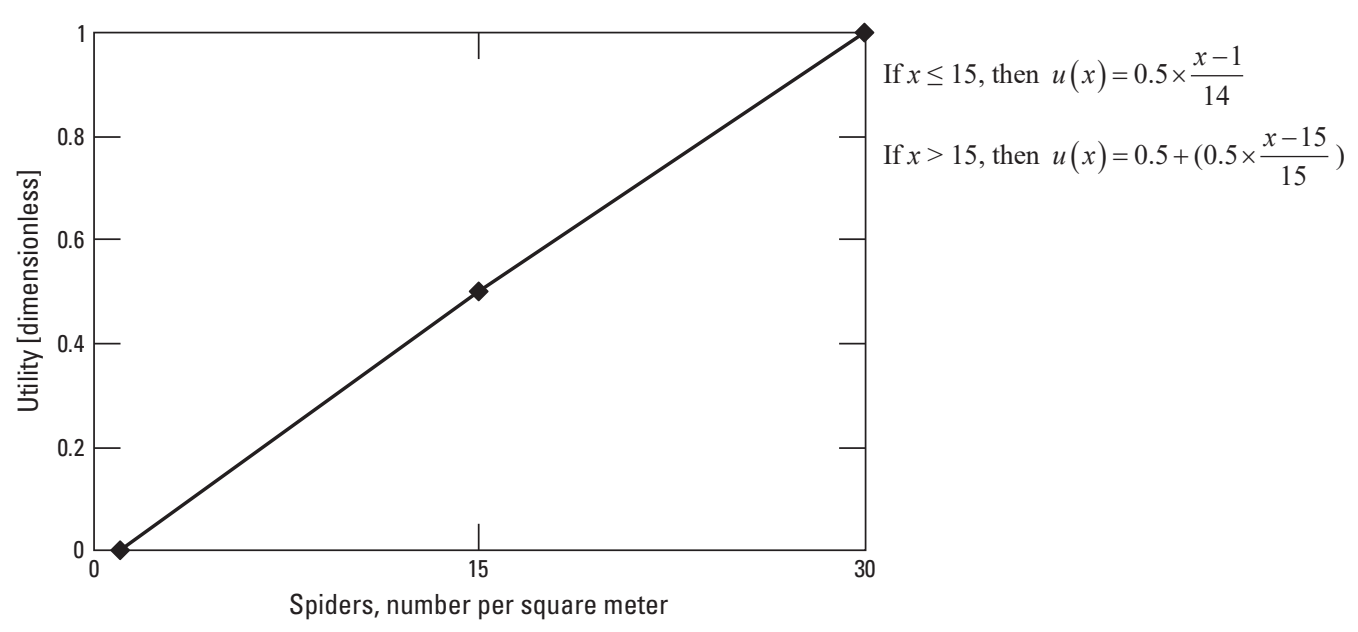

Figure 2.6. Marsh spiders at the Edwin B. Forsythe National Wildlife Refuge, New Jersey.

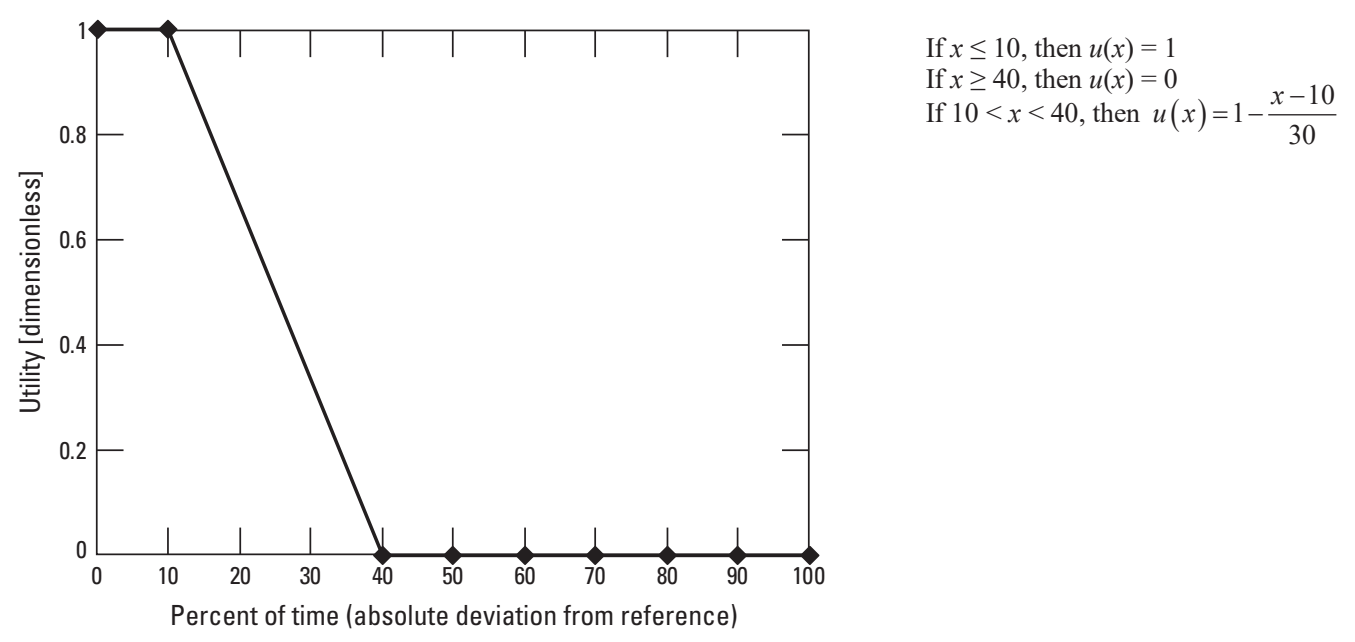

Figure 2.7. Duration of surface flooding at the Edwin B. Forsythe National Wildlife Refuge, New Jersey.

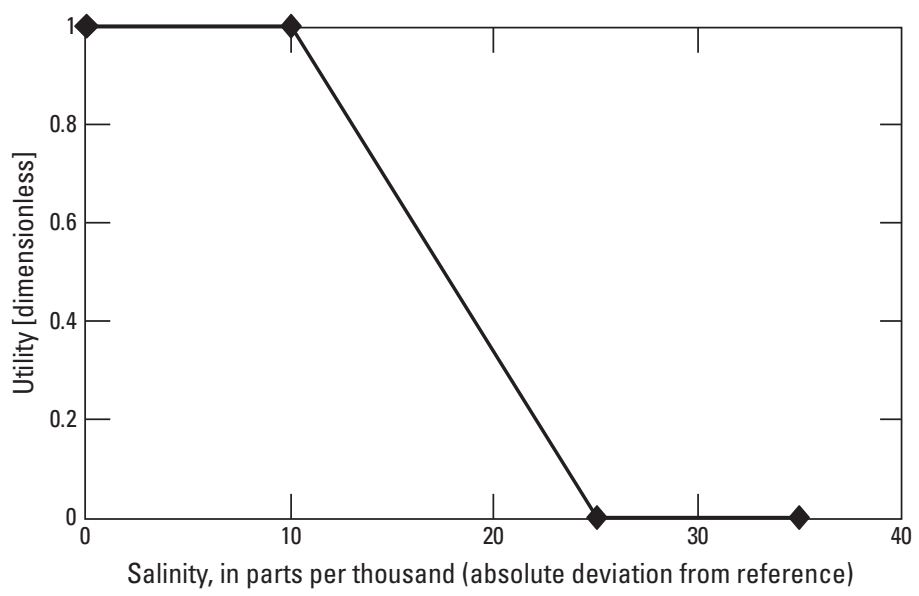

If $x \leq 10$, then $u(x)=1$

If $x \geq 25$, then $u(x)=0$

If $10<x<25$, then $u(x)=1-\frac{x-10}{15}$

Figure 2.8. Salinity of surface water at the Edwin B. Forsythe National Wildlife Refuge, New Jersey. 


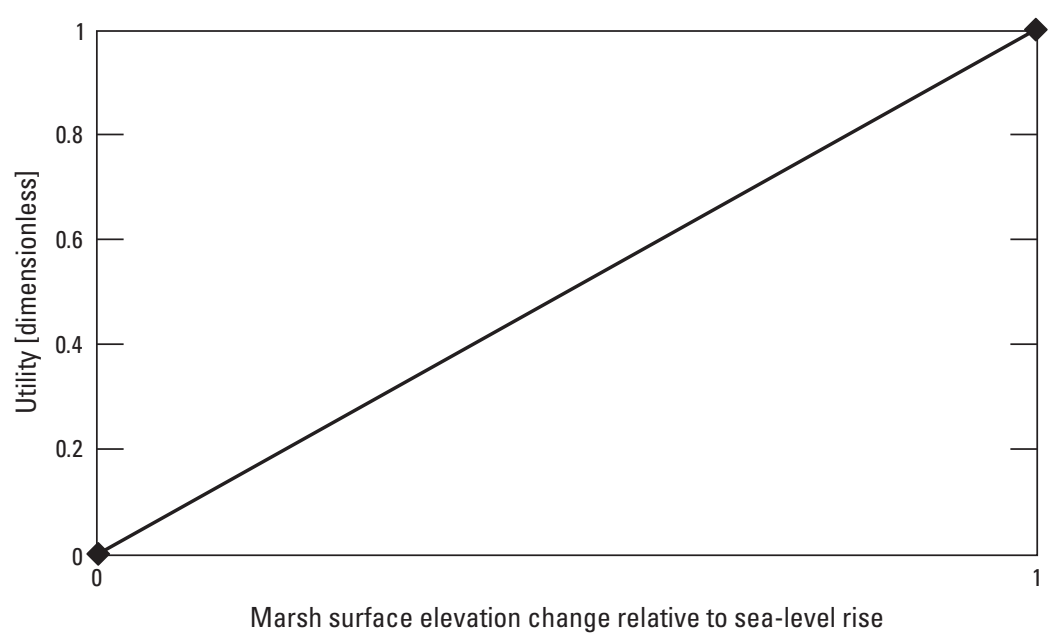

$$
\begin{aligned}
& u(x)=\frac{x-\text { Low }}{\text { High }- \text { Low }} \\
& \text { where } \\
& \qquad \begin{array}{c}
\text { Low } \quad=0, \text { lower than sea-level rise } \\
\text { High } \quad=1 \text {, above sea-level rise }
\end{array}
\end{aligned}
$$

Figure 2.9. Change in marsh surface elevation relative to sea-level rise at the Edwin B. Forsythe National Wildlife Refuge, New Jersey.

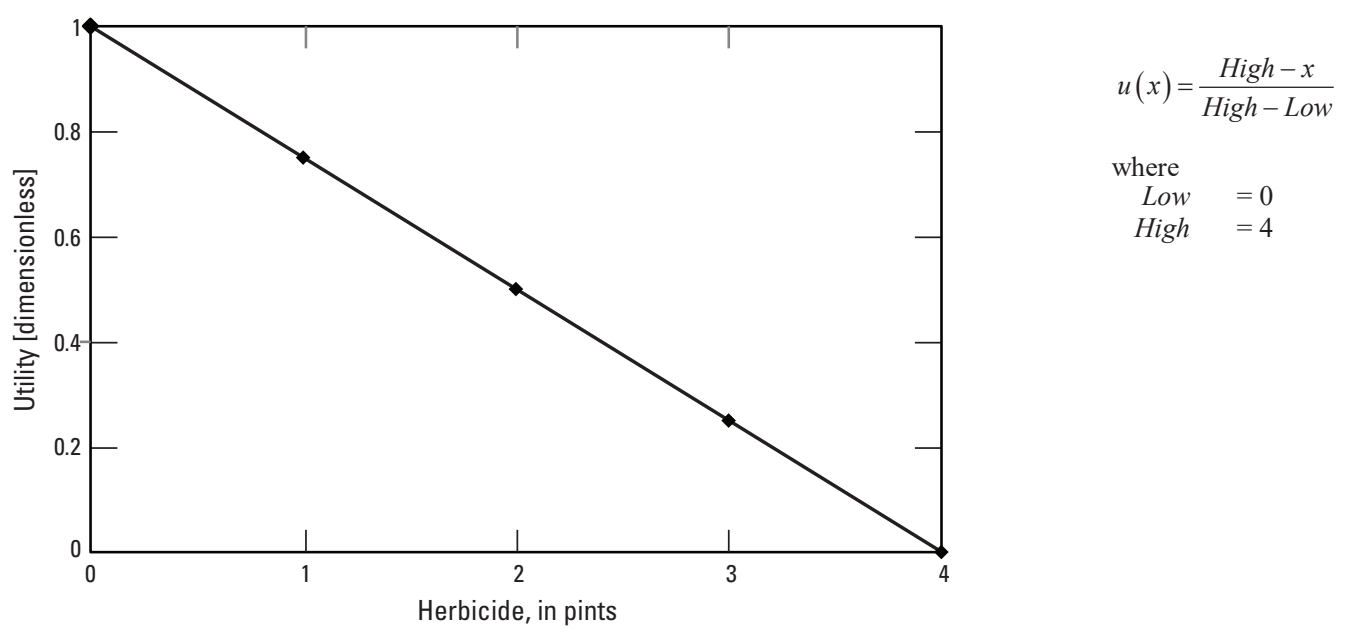

Figure 2.10. Application of herbicides at the Edwin B. Forsythe National Wildlife Refuge, New Jersey.

\section{Reference Cited}

Neckles, H.A., Lyons, J.E., Guntenspergen, G.R., Shriver, W.G., and Adamowicz, S.C., 2015, Use of structured decision making to identify monitoring variables and management priorities for salt marsh ecosystems: Estuaries and Coasts, v. 38, no. 4, p. 1215-1232. [Also available at https://doi.org/10.1007/s12237-014-9822-5.] 

For more information, contact:

Director, Eastern Ecological Science Center U.S. Geological Survey

11649 Leetown Road

Kearneysville, WV 25430

gs_naa_eesc@usgs.gov

or visit our website at

https://www.usgs.gov/centers/eesc

Publishing support provided by the Pembroke Publishing Service Center 
